\title{
Trends in energy and nutrient intake and risk of inadequate intakes in Catalonia, Spain (1992-2003)
}

\author{
Lluís Serra-Majem ${ }^{1,2,3, *}$, Lourdes Ribas-Barba ${ }^{1}$, Gemma Salvador $^{3}$, Lluís Jover ${ }^{4}$, \\ Blanca Raidó ${ }^{1}$, Joy $\mathrm{Ngo}^{1}$ and Antoni Plasencia ${ }^{3}$ \\ ${ }^{1}$ Community Nutrition Research Centre, University of Barcelona Science Park, Baldiri Reixac 4, Torre D 4A1, \\ 08028 Barcelona, Spain: ${ }^{2}$ Department of Clinical Sciences, University of Las Palmas de Gran Canaria, Las \\ Palmas de Gran Canaria, Spain: ${ }^{3}$ Division of Public Health, Department of Health, Generalitat of Catalonia, \\ Barcelona, Spain: ${ }^{4}$ Department of Public Health, University of Barcelona, Barcelona, Spain
}

Submitted 6 July 2007: Accepted 7 September 2007

\begin{abstract}
Objectives: To analyse trends in energy and nutrient intakes and nutritional adequacy from 1992 to 2003.

Design: Two consecutive cross-sectional studies carried out on random samples of the Catalan population ENCAT 1992-93 and ENCAT 2002-03. Dietary intake was assessed by means of two 24-hour recalls on non-consecutive days. Spanish food consumption tables were used. Energy and nutrient data were adjusted for intraindividual variability, and the Spanish recommend nutrient intakes (RNIs) were used in the analysis.

Setting: Catalonia region, North Eastern Spain.

Subjects: Analysis is based on a total of 4701 individuals; 2641 from ENCAT 1992-93 (1210 men and 1431 women) and 2060 from ENCAT 2002-03 (954 men and 1106 women), aged $10-75$ years.

Results: No relevant changes in energy intake trends were observed, although a decrease was observed in the daily consumption of proteins $(-7 \mathrm{~g})$, cholesterol $(-56 \mathrm{mg})$, potassium $(-245 \mathrm{mg})$, vitamin A $(-283 \mathrm{RE} \mu \mathrm{g})$, retinoids $(-71 \mu \mathrm{g})$, carotenoids $(-1520 \mu \mathrm{g})$, niacin $(-29 \mathrm{mg})$, folates $(-15 \mu \mathrm{g})$, vitamin $\mathrm{B}_{12}(-1.6 \mu \mathrm{g})$ vitamin $\mathrm{D}(-0.5 \mu \mathrm{g})$, fibre and iron, and an increase in the consumption of calcium ( $+57 \mathrm{mg}$ ) and a slight increase in lipids and fatty acids (\% energy). In general, the most outstanding trends were those of vitamin $\mathrm{A}$ (as a result of the decreased consumption of offal), proteins, vitamin $\mathrm{D}$ and $\mathrm{B}_{12}$ (due to the decreased consumption of meat and fish) and calcium (as a consequence of the increased consumption of dairy products).

Conclusion: No changes were observed in the energy intake of males or females; therefore, the obesity changes may possibly be attributed to changes in physical activity patterns. However, an increase in energy sources of a poorer nutritional profile has been identified, especially for between meal snacks.
\end{abstract}

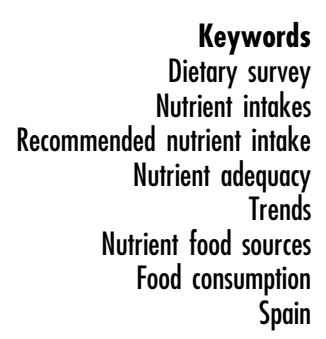

The World Health Organization (WHO) alerts in their World Health Report 2002 that in most developed countries, a great proportion of the morbidity and mortality are related to non-communicable diseases, and that the main risk factors (hypertension, hypercholesterolaemia, low fruit and vegetable consumption, overweight or obesity, physical inactivity and tobacco smoking) are largely related to inadequate food habits and low physical activity levels in the population ${ }^{1}$.

The evaluation of a population's nutritional status is a key element for the development of public health policies to promote healthy nutritional habits according to evidence-based epidemiology ${ }^{2,3}$. When the evaluation is conducted periodically, it is possible to analyse the evolution of the studied parameters, in order to assess the compliance with the nutrition objectives set for the population and the efficacy of nutritional policies and health promotion campaigns that have been carried out ${ }^{4,5}$. For this reason, the Health Department of the Autonomous Government of Catalonia has included as one of their objectives in the Health Policy for Catalonia, the realisation of periodic nutritional surveys for monitoring the nutritional status of the Catalan population $^{6,7}$. In fact, Catalonia has one of the most complete nutritional surveillance systems in Europe, with surveys conducted periodically in representative 
samples of the Catalan population $\left(1985-86^{8}, 1992-93^{9}\right.$ and $2002-03^{10}$ ).

The objective of this article is to evaluate trends in energy and nutrient intakes as well as nutrient inadequacy in the Catalan population during the period 1992-2003.

\section{Material and methods}

The nutritional data from the present study are derived from the last two Catalan Nutritional Surveys carried out in 1992-93 (ENCAT 1992-93) and 2002-03 (ENCAT 2002-03), whose methodology has been previously described in other publications ${ }^{9,10}$. The following summarises the methodology in relation to the present article.

\section{Sample}

Both surveys are based on a representative sample of the Catalan population taken from the population census by stratified sampling according to the population size and randomised in subgroups, with Catalan municipalities being the primary sample units, and individuals within these municipalities comprising the final units. The response rates in both surveys were similar, $69 \%$ and $65 \%$, respectively. The present analysis is based on data from 4701 individuals aged 10-75 years, pooled from the two surveys (2164 men and 2537 women): 2641 belonged to ENCAT 1992-93 (1210 men and 1431 women) and 2060 belonged to ENCAT 2002-03 (954 men and 1106 women) ${ }^{10,11}$.

\section{Methods}

Data were collected at the individual's home via personal interviews carried out by dietitians who had previously undergone a rigorous selection and training process. A 24-hour recall was used for dietary assessment. In ENCAT 1992-93, the 24-hour recall was carried out twice, the first time during a warm season (May-July 1992) and the second time during a cold season (November-December 1992), in order to avoid the influence of seasonal variations. In ENCAT 2002-03, during the March 2002-June 2003 period, all individuals completed one 24-hour recall, and $62 \%$ of the sample completed a second 24 -hour recall 8-30 days later, conducted on a different day from that of the first interview. In both surveys, interviews were conducted on all days of the week. In order to estimate volumes and portion sizes, the household measures found in the subjects' own homes were used. In the case of subjects with disabilities or memory defects the primary caretaker was interviewed. Children under 13 were assisted by a parent. Food data coding was carried out by the interviewers ${ }^{9-11}$.

Despite the fact that both surveys were based on similar methodologies, to avoid the possibility that changes in energy and nutrient intakes were linked to the fact that different food composition tables were utilised in each survey (ENCAT 1992-93 used the French tables ${ }^{12}$ and in ENCAT 2002-03 the Spanish tables developed by CESNID were applied ${ }^{13}$ ), the two 24-hour recalls obtained from the ENCAT 1992-93 survey were recoded according to the 635 food codes used in the ENCAT 2002-03 survey. In each survey, estimation of energy and nutrients was carried out separately for each of the two 24-hour recalls and data were adjusted for intraindividual variability using the method of analysis of variance as originally described by Beaton et al. ${ }^{14-17}$.

In order to evaluate inadequate or deficient energy and nutrient intakes, the updated version of the recommended nutrient intake (RNI) values elaborated by the Centro Superior de Investigaciones Científicas, Complutense University of Madrid (1994) for the Spanish population were used $^{18}$. They included energy and 14 nutrients, of which the recommendation for folate in females aged 13-49 years was doubled, resulting in a value of $400 \mu \mathrm{g} \mathrm{day}^{-1}$.

The study of energy and nutrient food sources was carried out by grouping into 20 food groups the 635 food codes used in the 24-hour recalls, following the same classification as the food composition table ${ }^{13}$.

\section{Analysis}

The data were analysed using SPSS statistical package (version 12.0). The differences of mean intakes for energy and nutrients by age and gender were analysed. Comparisons also included percentage of energy intake from fat, carbohydrate and proteins calculated from the following conversion factors - proteins: $4 \mathrm{kcal} \mathrm{g}^{-1}$; carbohydrates: $4 \mathrm{kcalg}^{-1}$, fats $9 \mathrm{kcalg}^{-1}$; alcohol $7 \mathrm{kcalg}^{-1}$. Nutrient inadequacy was assessed by calculating the percentage population with intakes $<1 / 3$ of RNI, $<1 / 2$ of the RNI, $<2 / 3$ of the RNI, or $<$ the RNI ${ }^{19}$. Moreover, the mean values for RNI percentages are also presented. The results of each survey are shown according to age group and gender.

Statistical analysis included Student's $t$-test to compare means between the two groups, and one-way analysis of variance to compare data from more than two groups. For non-parametric variables, the Mann-Whitney and Kruskal-Wallis tests were conducted, respectively. The $\chi^{2}$ statistics were used for comparison of proportions.

\section{Results}

Tables 1 and 2 present the 1992-2003 energy and nutrient consumption trends in the population aged 10-75 years, by age group, in men and women, respectively. The tables compare mean daily energy and nutrient consumption and the energy percentage distribution of the macronutrients by age group in each survey. The difference between the two surveys (ENCAT 2002-03 
Table 1 Trends 1992-2003 in energy and nutrient intake in Catalonia (men)

\begin{tabular}{|c|c|c|c|c|c|c|c|c|c|c|c|c|c|c|c|c|c|c|}
\hline \multicolumn{6}{|c|}{ ENCAT 1992-93 } & & \multicolumn{6}{|c|}{ ENCAT 2002-03 } & \multicolumn{6}{|c|}{ Difference (ENCAT 2002-03 minus ENCAT 1992-93) } \\
\hline \multicolumn{6}{|c|}{ Age group, years } & & \multicolumn{6}{|c|}{ Age group, years } & \multicolumn{6}{|c|}{ Age group, years } \\
\hline $\begin{array}{c}10-17 \\
n=167 \\
\text { Mean }\end{array}$ & $\begin{array}{c}18-24 \\
n=242 \\
\text { Mean }\end{array}$ & $\begin{array}{c}25-44 \\
n=372 \\
\text { Mean }\end{array}$ & $\begin{array}{c}45-64 \\
n=320 \\
\text { Mean }\end{array}$ & $\begin{array}{c}65-75 \\
n=110 \\
\text { Mean }\end{array}$ & $\begin{array}{c}\text { Total } \\
n=1211 \\
\text { Mean }\end{array}$ & & $\begin{array}{c}10-17 \\
n=114 \\
\text { Mean }\end{array}$ & $\begin{array}{c}18-24 \\
n=127 \\
\text { Mean }\end{array}$ & $\begin{array}{c}25-44 \\
n=326 \\
\text { Mean }\end{array}$ & $\begin{array}{c}45-64 \\
n=265 \\
\text { Mean }\end{array}$ & $\begin{array}{c}65-75 \\
n=122 \\
\text { Mean }\end{array}$ & $\begin{array}{c}\text { Total } \\
n=954 \\
\text { Mean }\end{array}$ & Dif. $P$ & Dif. $P$ & $25-44$ & $45-64$ & $65-75$ & Dif. $P$ \\
\hline 2354.6 & 2527.1 & 2292.7 & 1914.6 & 1814.6 & 2204.6 & Energy (kcal) & 2451.4 & 2383.9 & 2241.5 & 2017.7 & 1688.3 & 2152.6 & 96.9 & $-143.2 \mathrm{a}$ & -51.2 & $103.1 \mathrm{c}$ & $-126.2 b$ & -52.0 \\
\hline 1728.4 & 1996.2 & 1932.7 & 1826.5 & 1739.1 & 1871.5 & Water (g) & 1997.8 & 2077.1 & 2174.2 & 2037.3 & 1849.6 & 2060.6 & $269.3 \mathrm{c}$ & 81.0 & $241.4 \mathrm{c}$ & $210.8 \mathrm{c}$ & $110.4 a$ & $189.1 \mathrm{c}$ \\
\hline 102.8 & 113.3 & 110.5 & 96.4 & 90.2 & 104.4 & Total proteins $(\mathrm{g})$ & 105.0 & 104.1 & 101.2 & 95.4 & 77.6 & 97.4 & 2.2 & $-9.2 \mathrm{~b}$ & $-9.3 b$ & -0.9 & $-12.6 c$ & $\begin{array}{l}-7.0 \mathrm{c} \\
-12\end{array}$ \\
\hline 30.5 & 31.2 & 27.8 & 24.5 & 24.2 & 27.7 & Vegetable proteins $(\mathrm{g})$ & 29.9 & 28.4 & 27.0 & 25.3 & 22.7 & 26.5 & -0.6 & -2.9 & -0.8 & $0.8 b$ & -1.5 & -1.2 \\
\hline 71.6 & 81.3 & 82.2 & 70.9 & 64.8 & 76.0 & Animal proteins (g) & 73.5 & 74.6 & 72.6 & 68.9 & 54.1 & 69.6 & 1.9 & $-6.7 a$ & $-9.6 b$ & -2.0 & $-10.6 c$ & $-6.4 \mathrm{c}$ \\
\hline 105.5 & 111.5 & 99.4 & 77.4 & 71.0 & 94.3 & Total lipids (g) & 110.6 & 108.2 & 99.1 & 87.9 & 67.2 & 94.5 & 5.0 & -3.2 & -0.3 & $10.5 \mathrm{c}$ & -3.7 & 0.2 \\
\hline 35.9 & 36.5 & 31.8 & 23.3 & 20.8 & 30.0 & $\operatorname{SFA}(\mathrm{g})$ & 38.2 & 36.1 & 31.3 & 25.2 & 19.2 & 29.5 & 2.3 & -0.4 & -0.5 & $1.9 \mathrm{c}$ & -1.6 & -0.5 \\
\hline 44.2 & 48.2 & 43.9 & 35.7 & 33.3 & 41.7 & MUFA (g) & 45.4 & 44.7 & 43.9 & 39.7 & 31.3 & 41.4 & 1.2 & -3.4 & -0.1 & $4.0 \mathrm{c}$ & -1.9 & -0.3 \\
\hline 17.3 & 17.8 & 14.8 & 12.7 & 10.9 & 14.8 & PUFA (g) & 15.3 & 16.0 & 13.9 & 13.3 & 9.9 & 13.7 & -2.0 & -1.8 & -0.8 & $0.6 \mathrm{c}$ & -1.0 & -1.1 \\
\hline 410.8 & 440.5 & 471.7 & 390.0 & 328.4 & 422.4 & Cholesterol (mg) & 366.2 & 409.3 & 373.0 & 364.3 & 263.0 & 360.6 & $-44.6 b$ & $-31.2 c$ & $-98.7 c$ & -25.8 & $-65.4 c$ & $-61.9 c$ \\
\hline 256.0 & 263.2 & 212.5 & 187.8 & 183.4 & 219.5 & Carbohydrates (g) & 264.0 & 241.6 & 225.6 & 190.2 & 172.9 & 215.7 & $8.0 a$ & -21.6 & $13.1 \mathrm{~b}$ & 2.4 & -10.5 & -3.7 \\
\hline 97.4 & 93.3 & 82.7 & 74.4 & 78.3 & 84.3 & Digestible sugars (g) & 102.4 & 97.8 & 92.4 & 78.3 & 74.2 & 88.1 & 4.9 & 4.5 & $9.7 \mathrm{c}$ & $4.0 \mathrm{~b}$ & -4.2 & $3.8 \mathrm{c}$ \\
\hline 149.1 & 156.9 & 122.2 & 102.5 & 97.8 & 125.4 & Polysaccharides (g) & 154.7 & 141.8 & 127.9 & 108.1 & 96.3 & 123. & $5.5 \mathrm{a}$ & $-15.1 a$ & & 5.6 & -1.5 & -2.0 \\
\hline 20.3 & 21.0 & 20.3 & 20.9 & 21.5 & 20.7 & Fibre $(\mathrm{g})$ & 18.7 & 18.6 & 18.7 & 20.2 & 19.3 & 19.2 & -1.6 & $-2.4 b$ & $-1.6 b$ & -0.7 & $-2.2 b$ & $-1.5 \mathrm{c}$ \\
\hline 0.4 & 7.8 & 14.1 & 11.7 & 9.3 & 9.9 & Alcohol (g) & 0.1 & 5.5 & 8.1 & 12.6 & 10.3 & 8.3 & -0.4 & $-2.3 c$ & $-6.0 \mathrm{~b}$ & 0.9 & $1.0 a$ & -1.6 \\
\hline 3037.8 & 3475.9 & 3211.6 & 2533.2 & 2456.9 & 2992.5 & Sodium (mg) & 3407.2 & 3382.8 & 3155.6 & 2764.2 & 2232.0 & 2989.1 & $369.4 \mathrm{c}$ & -93.2 & -56.0 & $230.9 \mathrm{c}$ & -225.0 & $-3.4 a$ \\
\hline 3123.5 & 3276.6 & 3306.2 & 3216.8 & 3219.1 & 3243.5 & Potassium (mg) & 2934.8 & 2981.6 & 2977.5 & 3117.0 & 2790.1 & 2987.7 & -188.7 & $-295.0 \mathrm{~b}$ & $-328.8 \mathrm{c}$ & -99.8 & $-429.0 \mathrm{c}$ & $-255.8 \mathrm{c}$ \\
\hline 879.7 & 848.1 & 780.0 & 688.2 & 677.8 & 773.8 & & 959.1 & 934.4 & 839.6 & 770.0 & 744.5 & 835.0 & $79.4 a$ & $86.3 \mathrm{~b}$ & $59.6 \mathrm{c}$ & $81.8 \mathrm{c}$ & $66.7 \mathrm{c}$ & $61.2 \mathrm{c}$ \\
\hline 303.4 & 316.1 & 312.0 & 293.1 & 295.0 & 305. & Magne & 298.5 & 306.9 & 306.8 & 311.8 & 281.5 & 304.0 & -4.9 & -9.2 & -5.2 & $18.6 \mathrm{c}$ & -13.4 & -1.1 \\
\hline 1464.5 & 1551.0 & 1485.9 & 1280.9 & 1205.8 & 1416.3 & $P$ & 1523.6 & 1536.0 & 1438.9 & 1342.1 & 1144.4 & 1397.4 & 59.1 & -15.0 & -47.0 & $61.2 \mathrm{c}$ & -61.5 & -18.9 \\
\hline 14.5 & 14.9 & 14.8 & 13.7 & & & & 13.0 & 13.2 & 12.8 & 13.1 & 11.1 & 12.8 & $-1.4 b$ & $-1.7 \mathrm{~b}$ & $-1.9 \mathrm{c}$ & -0.6 & $-2.6 c$ & $-1.6 \mathrm{c}$ \\
\hline 10.3 & 11.1 & 10.3 & 9.1 & 8.5 & 10 & Zinc (mg) & 10.4 & 10.3 & 9.5 & 8.9 & 7.5 & 9.3 & 0.1 & $-0.8 a$ & $-0.8 b$ & -0.2 & $-1.1 \mathrm{c}$ & $-0.7 \mathrm{c}$ \\
\hline 736.1 & 754.0 & 892.6 & 855.8 & 901.9 & 834 & Total vitamin A (RE $\mu \mathrm{g})$ & 551.4 & 559.6 & 537.1 & 556.1 & 454.2 & 536.5 & $-184.7 a$ & $-194.4 \mathrm{c}$ & $-355.4 \mathrm{c}$ & $-299.7 \mathrm{c}$ & $-447.7 \mathrm{c}$ & $-297.9 \mathrm{c}$ \\
\hline 410.3 & 340.7 & 309.3 & 227.6 & 249.2 & & & 296.0 & 310.1 & 277.7 & 222.8 & 187.2 & 257.4 & -114.3 & -30.5 & $-31.6 a$ & $-4.8 \mathrm{c}$ & $-62.0 \mathrm{~b}$ & $-45.1 \mathrm{~b}$ \\
\hline 1925.5 & 2271.0 & 3142.2 & 3729.7 & 3865.2 & 3021.1 & Carote & 1219.4 & 1244.7 & 1221.1 & 1560.4 & 1248.2 & 1321.8 & -706.2 & $-1026.3 c$ & $-1921.0 c$ & $-2169.3 c$ & $-2617.0 \mathrm{c}$ & $-1699.4 \mathrm{c}$ \\
\hline 1.4 & 2.7 & 3.4 & 1.1 & 3.3 & 2. & & 1.7 & 1.9 & 1.7 & 1.3 & 0.7 & 1.5 & $0.3 \mathrm{c}$ & $-0.8 a$ & -1.7 & $0.2 \mathrm{c}$ & -2.6 & $-0.9 \mathrm{c}$ \\
\hline 9.7 & 10.0 & 10.7 & 9.3 & 9.6 & 9.9 & Vitamin E (T.E. mg) & 8.8 & 9.3 & 9.3 & 9.8 & 8.4 & 9.3 & -0.9 & -0.6 & $-1.3 a$ & $0.5 \mathrm{c}$ & -1.2 & -0.7 \\
\hline 1.7 & 1.6 & 1.5 & 1.2 & & & & 1.7 & 1.6 & 1.4 & 1.2 & 1.0 & 1 & 0.0 & -0 & -0.1 & 0.0 & $-0.2 c$ & $-0.1 \mathrm{a}$ \\
\hline 1.9 & 1.8 & 1.7 & 1.5 & 1. & 1 & & 1.9 & 1.8 & 1.6 & 1.5 & 1.3 & 1. & 0.0 & 0.0 & $-0.1 \mathrm{a}$ & $0.1 \mathrm{c}$ & $-0.1 \mathrm{a}$ & -0.1 \\
\hline 22.6 & 26.0 & 26.0 & 22.7 & 22. & 24.3 & & 22.3 & 21.7 & 22.5 & 21.0 & 16.1 & 21.1 & -0.3 & $-4.3 c$ & $-3.5 c$ & $-1.7 a$ & $-6.4 \mathrm{c}$ & $-3.2 \mathrm{c}$ \\
\hline 2.0 & 2.1 & 2.1 & 1.9 & 1.9 & 2.0 & & 2.1 & 2.0 & 2.0 & 2.0 & 1.7 & 2. & 0.1 & -0.1 & -0 & $0.1 \mathrm{c}$ & $-0.2 \mathrm{c}$ & 0.0 \\
\hline 248.5 & 263.4 & 250.5 & 249.2 & 272.0 & 254.4 & Folates $(\mu$ & 237.5 & 226.9 & 231.4 & 248.2 & 232.1 & 236.3 & -11.0 & $-36.5 a$ & $-19.1 a$ & -1.0 & $-39.9 a$ & -18.1 \\
\hline 6.1 & 6.6 & 8.1 & 6.7 & 7.4 & 7.1 & Vitamin $B_{12}$ & 4.8 & 5.0 & 4.9 & 5.2 & 3.8 & 4.8 & -1.3 & -1.6 & $-3.1 c$ & -1.5 & -3.6 & $-2.2 b$ \\
\hline 76.9 & 93.7 & 94.6 & 109.7 & 120.1 & 98.3 & & 73.4 & 73.9 & 93.1 & 110.4 & 122.2 & 96.7 & -3.5 & -19.8 & -1 & $0.7 \mathrm{~b}$ & 2.1 & $-1.6 \mathrm{c}$ \\
\hline 17.6 & 18.2 & 20.2 & 21.1 & & & Protei & 17. & 18.0 & 18.8 & 20.0 & 19.5 & 18. & -0.4 & -0.3 & $-1.4 \mathrm{c}$ & $-1.1 \mathrm{c}$ & -1.1 & $-0.8 \mathrm{c}$ \\
\hline 40.0 & 40.5 & 40.3 & & & & & 40 & 41.7 & 41. & 41 & 37 & 40 & 0.5 & 1.2 & 0.8 & $3.8 \mathrm{c}$ & 1.3 & $1.5 \mathrm{c}$ \\
\hline 13.6 & 13.2 & 12.7 & 11.2 & 10.7 & 12.4 & rgy) & 14.0 & 14.0 & 13.0 & 11.8 & 10.8 & 12.6 & 0.4 & $0.8 \mathrm{c}$ & $0.2 a$ & $0.6 \mathrm{c}$ & 0.1 & $0.3 \mathrm{c}$ \\
\hline 16.8 & 17.4 & 17.9 & 17.2 & 17. & 17 & MUFA (\% energy) & 16.7 & 17.2 & 18.2 & 18 & 17.5 & 17. & -0 & -0.2 & 0.3 & $1.3 \mathrm{c}$ & 0.4 & 0.5 \\
\hline 6.5 & 6.4 & 6.0 & 6.0 & 5.5 & 6.1 & & 5. & 6.2 & 5.9 & 6.2 & 5.5 & 5.9 & -0.8 & -0.2 & -0.2 & $0.2 \mathrm{c}$ & 0.0 & $-0.2 \mathrm{c}$ \\
\hline 43.6 & 42.1 & 38.7 & 41.2 & 42.3 & 41.0 & Carbohydrates (\% energy) & 43.4 & 41.4 & 41.1 & 39.4 & 43.0 & 41.2 & -0.2 & -0.7 & $2.4 \mathrm{c}$ & $-1.8 \mathrm{a}$ & 0.7 & $0.2 \mathrm{a}$ \\
\hline 16.5 & 15.0 & 15.1 & 16.6 & 18.3 & 16.0 & Digestible Sugars (\% energy) & 16.8 & 16.7 & 16.7 & 16.4 & 18.5 & 16. & 0.3 & $1.7 \mathrm{c}$ & $1.6 \mathrm{c}$ & -0.2 & 0.2 & $0.9 \mathrm{c}$ \\
\hline 25.3 & 25.0 & 22.0 & 22.2 & 22.3 & 23.2 & Polysaccharides (\% energy) & 25.6 & 24.3 & 23.4 & 22.3 & 23.9 & 23.6 & 0.3 & -0.7 & $1.4 \mathrm{c}$ & 0.1 & $1.6 \mathrm{a}$ & 0.4 \\
\hline
\end{tabular}

SFA - saturated fatty acids; MUFA - monounsaturated fatty acids; PUFA - polyunsaturated fatty acids.

Significance: $\mathrm{a}=P<0.05 ; \mathrm{b}=P<0.01 ; \mathrm{c}=P<0.001$. 
Table 2 Trends 1992-2003 in energy and nutrient intake in Catalonia (women)

\begin{tabular}{|c|c|c|c|c|c|c|c|c|c|c|c|c|c|c|c|c|c|c|}
\hline \multicolumn{6}{|c|}{ ENCAT 1992-93 } & & \multicolumn{6}{|c|}{ ENCAT 2002-03 } & \multicolumn{6}{|c|}{ Difference (ENCAT 2002-03 minus ENCAT 1992-93) } \\
\hline \multicolumn{6}{|c|}{ Age group, years } & & \multicolumn{6}{|c|}{ Age group, years } & \multicolumn{6}{|c|}{ Age group, years } \\
\hline $\begin{array}{c}10-17 \\
n=148 \\
\text { Mean }\end{array}$ & $\begin{array}{c}18-24 \\
n=299 \\
\text { Mean }\end{array}$ & $\begin{array}{c}25-44 \\
n=458 \\
\text { Mean }\end{array}$ & $\begin{array}{c}45-64 \\
n=372 \\
\text { Mean }\end{array}$ & $\begin{array}{c}65-75 \\
n=154 \\
\text { Mean }\end{array}$ & $\begin{array}{c}\text { Total } \\
n=1431 \\
\text { Mean }\end{array}$ & & $\begin{array}{l}10-17 \\
n=89 \\
\text { Mean }\end{array}$ & $\begin{array}{c}18-24 \\
n=182 \\
\text { Mean }\end{array}$ & $\begin{array}{c}25-44 \\
n=376 \\
\text { Mean }\end{array}$ & $\begin{array}{c}45-64 \\
n=337 \\
\text { Mean }\end{array}$ & $\begin{array}{c}65-75 \\
n=122 \\
\text { Mean }\end{array}$ & $\begin{array}{c}\text { Total } \\
n=1106 \\
\text { Mean }\end{array}$ & $10-17$ & $18-24$ & $25-44$ & $45-64$ & $\begin{array}{l}65-75 \\
\text { Dif. } P\end{array}$ & Total \\
\hline 2115.7 & 1818.8 & 1677.3 & 1571.1 & 1455.9 & 1700.8 & Energy (kcal) & 1950.0 & 1868.8 & 1713.8 & 1572.6 & 1373.3 & 1677.7 & $-165.7 a$ & 50.0 & 36.5 & 1.5 & $-82.6 \mathrm{~b}$ & -23.0 \\
\hline 1663.8 & 1748.1 & 1787.1 & 1749.2 & 1589.2 & 1735.1 & Water $(\mathrm{g})$ & 1844.9 & 1844.8 & 1908.6 & 1909.3 & 1723.5 & 1872.8 & $181.1 \mathrm{c}$ & $96.8 \mathrm{~b}$ & $121.5 \mathrm{c}$ & $160.0 \mathrm{c}$ & $134.2 \mathrm{~b}$ & $137.7 \mathrm{c}$ \\
\hline 93.4 & 87.9 & 85.8 & 84.7 & 79.4 & 86.0 & Total proteins $(\mathrm{g})$ & 86.4 & 83.7 & 80.8 & 76.4 & 68.0 & 79.0 & $-7.0 \mathrm{a}$ & -4.2 & $-5.0 \mathrm{a}$ & $-8.3 c$ & $-11.4 \mathrm{c}$ & $-7.1 \mathrm{c}$ \\
\hline 25.3 & 20.8 & 19.3 & 19.0 & 18.6 & 20.1 & Vegetable proteins (g) & 25.2 & 22.4 & 20.8 & 19.8 & 19.0 & 20.9 & -0.1 & $1.6 \mathrm{c}$ & $1.5 \mathrm{c}$ & $0.8 \mathrm{~b}$ & 0.4 & $0.8 \mathrm{c}$ \\
\hline 67.3 & 66.6 & 64.0 & 65.3 & 56.7 & 64.4 & Animal proteins $(\mathrm{g})$ & 60.1 & 60.3 & 58.7 & 55.1 & 47.5 & 56.8 & $-7.3 \mathrm{a}$ & $-6.3 a$ & $-5.3 c$ & $-10.1 c$ & $-9.2 \mathrm{c}$ & $-7.7 \mathrm{c}$ \\
\hline 96.8 & 83.0 & 74.4 & 65.0 & 56.4 & 74.1 & Total lipids (g) & 87.1 & 84.8 & 77.3 & 67.5 & 57.4 & 74.1 & $-9.7 \mathrm{~b}$ & 1.8 & $2.9 b$ & $2.6 \mathrm{~b}$ & 0.9 & 0.0 \\
\hline 33.2 & 27.6 & 24.4 & 20.2 & 17.2 & 24.1 & SFA (g) & 29.6 & 27.4 & 24.3 & 20.0 & 16.6 & 23.1 & $-3.7 a$ & -0.2 & -0.1 & -0.1 & -0.6 & -1.0 \\
\hline 41.0 & 36.1 & 33.5 & 30.4 & 26.2 & 33.2 & MUFA (g) & 36.7 & 36.0 & 34.1 & 30.9 & 26.7 & 32.8 & $-4.3 a$ & -0.1 & 0.6 & $0.5 a$ & 0.5 & -0.4 \\
\hline 12.5 & 12.5 & 10.8 & 9.0 & 8.2 & 10.6 & PUFA (g) & 11.9 & 12.4 & 10.9 & 9.6 & 8.2 & 10.5 & $-0.6 c$ & -0.1 & $0.1 c$ & $0.6 \mathrm{c}$ & 0.0 & $-0.1 \mathrm{c}$ \\
\hline 392.0 & 343.3 & 342.5 & 300.8 & 284.8 & 330.8 & Cholesterol (mg) & 314.4 & 299.6 & 300.2 & 263.1 & 209.4 & 279.9 & $-77.6 c$ & $-43.7 \mathrm{c}$ & $-42.4 c$ & $-37.8 c$ & $-75.4 c$ & $-50.9 c$ \\
\hline 217.9 & 180.9 & 162.4 & 157.5 & 153.3 & 169.8 & Carbohydrates (g) & 211.4 & 189.9 & 172.3 & 155.4 & 142.7 & 169.9 & -6.5 & $9.0 \mathrm{~b}$ & $9.8 \mathrm{c}$ & -2.2 & $-10.6 b$ & 0.1 \\
\hline 89.6 & 78.0 & 77.4 & 75.4 & 75.5 & 78.1 & Digestible sugars (g) & 82.1 & 80.0 & 77.0 & 75.1 & 67.9 & 76.3 & -7.5 & 2.0 & -0.4 & -0.3 & $-7.6 c$ & -1.8 \\
\hline 124.7 & 94.2 & 79.2 & 75.2 & 72.5 & 85.3 & Polysaccharides (g) & 123.6 & 105.6 & 89.8 & 75.5 & 72.1 & 88.8 & -1.1 & $11.4 \mathrm{c}$ & $10.5 \mathrm{c}$ & 0.3 & -0.5 & $3.5 \mathrm{c}$ \\
\hline 18.1 & 16.7 & 17.5 & 18.3 & 18.8 & 17.7 & Fibre (g) & 17.4 & 15.4 & 16.5 & 18.1 & 17.5 & 17.0 & -0.7 & -1.3 & -1.0 & -0.1 & $-1.3 a$ & $-0.7 \mathrm{a}$ \\
\hline 0.1 & 1.6 & 3.1 & 3.0 & 2.0 & 2.3 & Alcohol (g) & 1.3 & 2.5 & 2.2 & 4.3 & 2.6 & 2.9 & $1.2 \mathrm{a}$ & $0.9 \mathrm{c}$ & $-0.9 c$ & $1.3 \mathrm{c}$ & $0.6 \mathrm{c}$ & $0.5 \mathrm{~b}$ \\
\hline 2800.8 & 2353.0 & 2065.5 & 1947.0 & 1738.9 & 2135.7 & Sodium (mg) & 2741.1 & 2599.1 & 2271.6 & 1990.8 & 1733.5 & 2218.4 & -59.7 & $246.0 \mathrm{c}$ & $206.1 \mathrm{c}$ & $43.8 \mathrm{~b}$ & -5.4 & $82.7 \mathrm{c}$ \\
\hline 2878.4 & 2727.5 & 2963.8 & 2993.2 & 2975.9 & 2914.5 & Potassium (mg) & 2534.9 & 2495.5 & 2668.5 & 2829.1 & 2643.2 & 2675.4 & $-343.5 c$ & $-232.0 \mathrm{c}$ & $-295.3 c$ & $-164.1 \mathrm{~b}$ & $-332.6 c$ & $-239.1 c$ \\
\hline 814.8 & 731.4 & 726.5 & 696.7 & 682.3 & 724.1 & Calcium (mg) & 835.7 & 787.7 & 770.7 & 782.7 & 725.1 & 777.4 & 20.9 & $56.3 \mathrm{c}$ & $44.2 \mathrm{c}$ & $86.0 \mathrm{c}$ & $42.8 \mathrm{~b}$ & $53.2 \mathrm{c}$ \\
\hline 273.0 & 258.6 & 262.0 & 269.0 & 269.3 & 265.1 & Magnesium (mg) & 269.5 & 256.6 & 265.7 & 278.7 & 262.3 & 268.1 & -3.5 & -2.0 & 3.6 & $9.7 \mathrm{~b}$ & -7.0 & $3.1 \mathrm{a}$ \\
\hline 1356.8 & 1248.1 & 1218.2 & 1170.8 & 1112.4 & 1215.1 & Phosphorus (mg) & 1289.6 & 1250.0 & 1213.4 & 1152.8 & 1044.7 & 1188.5 & -67.2 & 1.8 & -4.8 & -18.0 & $-67.7 \mathrm{~b}$ & -26.6 \\
\hline 12.8 & 11.6 & 11.9 & 11.9 & 11.1 & 11.9 & Iron $(\mathrm{mg})$ & 11.2 & 10.5 & 10.5 & 10.5 & 9.6 & 10.5 & $-1.6 c$ & $-1.1 b$ & $-1.4 \mathrm{c}$ & $-1.4 \mathrm{c}$ & $-1.5 c$ & $-1.4 \mathrm{c}$ \\
\hline 9.5 & 8.6 & 8.5 & 8.2 & 7.3 & 8.4 & Zinc $(\mathrm{mg})$ & 8.7 & 8.3 & 7.8 & 7.5 & 6.8 & 7.7 & -0.8 & -0.4 & $-0.7 \mathrm{c}$ & $-0.7 \mathrm{c}$ & -0.5 & $-0.7 \mathrm{c}$ \\
\hline 532.5 & 575.1 & 978.1 & 860.7 & 485.0 & 764.2 & Total vitamin A (RE $\mu \mathrm{g})$ & 506.3 & 489.2 & 483.2 & 538.1 & 403.9 & 494.0 & $-26.2 b$ & $-85.9 c$ & $-494.9 c$ & $-322.5 c$ & $-81.1 \mathrm{c}$ & $-270.2 \mathrm{c}$ \\
\hline 373.3 & 241.8 & 422.3 & 245.6 & 236.9 & 313.6 & Retinoids $(\mu \mathrm{g})$ & 286.4 & 254.0 & 221.8 & 215.4 & 140.0 & 221.3 & -86.9 & $12.2 \mathrm{c}$ & -200.5 & -30.2 & -96.9 & $-92.3 c$ \\
\hline 2273.1 & 2365.2 & 2772.7 & 3604.8 & 1737.9 & 2740.9 & Carotenoids $(\mu \mathrm{g})$ & 1060.9 & 1059.2 & 1318.5 & 1723.5 & 1277.0 & 1373.9 & $-1212.2 \mathrm{c}$ & $-1305.9 \mathrm{c}$ & $-1454.3 c$ & $-1881.4 \mathrm{C}$ & $-460.9 c$ & $-1366.9 \mathrm{c}$ \\
\hline 1.1 & 1.3 & 1.5 & 1.9 & 0.7 & 1.4 & Vitamin D $(\mu \mathrm{g})$ & 1.6 & 1.5 & 1.4 & 1.0 & 0.6 & 1.2 & $0.4 \mathrm{c}$ & $0.2 \mathrm{c}$ & $-0.1 \mathrm{c}$ & $-0.9 a$ & $-0.1 \mathrm{c}$ & $-0.2 \mathrm{c}$ \\
\hline 9.0 & 8.4 & 8.9 & 8.5 & 8.1 & 8.6 & Vitamin E (T.E. mg) & 7.8 & 8.3 & 8.3 & 8.7 & 7.5 & 8.3 & -1.1 & -0.1 & -0.6 & $0.2 \mathrm{c}$ & -0.6 & -0.3 \\
\hline 1.5 & 1.3 & 1.2 & 1.1 & 1.1 & 1.2 & Thiamine (mg) & 1.3 & 1.3 & 1.1 & 1.1 & 1.0 & 1.1 & $-0.2 b$ & 0.0 & 0.0 & 0.0 & -0.1 & -0.1 \\
\hline 1.7 & 1.5 & 1.5 & 1.4 & 1.4 & 1.5 & Riboflavin (mg) & 1.6 & 1.5 & 1.4 & 1.4 & 1.3 & 1.4 & -0.2 & -0.1 & -0.1 & -0.1 & $-0.1 b$ & $-0.1 b$ \\
\hline 20.9 & 20.4 & 19.4 & 20.4 & 17.6 & 19.8 & Niacin $(\mathrm{mg})$ & 18.5 & 17.9 & 17.7 & 16.7 & 14.3 & 17.1 & $-2.4 b$ & $-2.5 c$ & $-1.7 c$ & $-3.8 \mathrm{c}$ & $-3.3 \mathrm{c}$ & $-2.7 \mathrm{c}$ \\
\hline 1.8 & 1.7 & 1.7 & 1.7 & 1.7 & 1.7 & Vitamin $B_{6}(\mathrm{mg})$ & 1.8 & 1.7 & 1.7 & 1.7 & 1.5 & 1.7 & 0.0 & -0.1 & -0.1 & 0.0 & -0.1 & 0.0 \\
\hline 236.7 & 222.9 & 232.4 & 233.4 & 234.1 & 231.3 & Folates $(\mu \mathrm{g})$ & 203.9 & 198.0 & 215.9 & 235.3 & 219.1 & 218.3 & $-32.8 b$ & -24.9 & -16.5 & $1.9 a$ & $-15.0 \mathrm{~b}$ & -13.1 \\
\hline 6.5 & 6.6 & 4.8 & 4.3 & 3.5 & 5.1 & Vitamin $B_{12}(\mu \mathrm{g})$ & 3.9 & 4.0 & 3.9 & 4.2 & 3.4 & 4.0 & -2.6 & -2.6 & $-0.9 \mathrm{c}$ & -0.1 & -0.1 & $-1.1 \mathrm{c}$ \\
\hline 74.9 & 85.3 & 111.1 & 117.6 & 122.9 & 104.9 & Vitamin C (mg) & 76.0 & 78.6 & 96.7 & 135.2 & 119.0 & 106.2 & 1.0 & -6.7 & -14.4 & $17.6 \mathrm{c}$ & -3.9 & $1.3 \mathrm{c}$ \\
\hline 17.9 & 19.5 & 20.7 & 22.0 & 21.9 & 20.6 & Proteins (\% energy) & 17.8 & 18.5 & 19.4 & 20.2 & 20.2 & 19.4 & -0.1 & -1.0 & $-1.3 c$ & $-1.8 \mathrm{c}$ & $-1.6 b$ & $-1.2 \mathrm{c}$ \\
\hline 40.6 & 40.9 & 39.9 & 37.2 & 34.8 & 38.9 & Lipids (\% energy) & 40.9 & 41.4 & 41.4 & 39.6 & 38.1 & 40.5 & 0.2 & 0.5 & $1.5 b$ & $2.4 \mathrm{c}$ & $3.3 \mathrm{c}$ & $1.5 \mathrm{c}$ \\
\hline 13.9 & 13.6 & 13.0 & 11.5 & 10.5 & 12.6 & SFA (\% energy) & 13.8 & 13.4 & 13.0 & 11.7 & 11.0 & 12.5 & -0.1 & -0.2 & -0.1 & 0.2 & $0.5 \mathrm{c}$ & -0.1 \\
\hline 17.2 & 17.8 & 18.0 & 17.4 & 16.2 & 17.5 & MUFA (\% energy) & 17.2 & 17.6 & 18.2 & 18.2 & 17.7 & 18.0 & 0.0 & -0.2 & 0.2 & $0.8 \mathrm{~b}$ & $1.6 \mathrm{c}$ & $0.5 \mathrm{c}$ \\
\hline 5.5 & 6.0 & 5.7 & 5.1 & 5.0 & 5.5 & PUFA (\% energy) & 5.6 & 6.0 & 5.9 & 5.6 & 5.4 & 5.8 & 0.0 & 0.0 & $0.2 \mathrm{c}$ & $0.5 \mathrm{c}$ & $0.4 \mathrm{c}$ & $0.2 \mathrm{c}$ \\
\hline 41.6 & 39.7 & 39.1 & 40.8 & 42.7 & 40.3 & Carbohydrates (\% energy) & 43.7 & 41.5 & 40.6 & 40.4 & 42.1 & 41.1 & $2.1 \mathrm{c}$ & $1.8 \mathrm{c}$ & $1.5 \mathrm{c}$ & -0.4 & -0.6 & $0.8 \mathrm{c}$ \\
\hline 17.1 & 17.6 & 18.7 & 19.8 & 21.3 & 18.9 & Digestible Sugars (\% energy) & 17.1 & 17.6 & 18.3 & 19.7 & 20.1 & 18.7 & -0.1 & 0.0 & -0.4 & -0.1 & $-1.2 \mathrm{a}$ & -0.2 \\
\hline 23.4 & 20.4 & 18.8 & 19.2 & 19.9 & 19.8 & Polysaccharides (\% energy) & 25.5 & 23.1 & 21.1 & 19.7 & 21.3 & 21.4 & $2.1 \mathrm{~b}$ & $2.7 \mathrm{c}$ & $2.2 \mathrm{c}$ & 0.5 & $1.4 a$ & $1.5 \mathrm{c}$ \\
\hline
\end{tabular}

FA - saturated fatty acids; MUFA - monounsaturated fatty acids; PUFA - polyunsaturated fatty acids.

Significance: $\mathrm{a}=P<0.05 ; \mathrm{b}=P<0.01 ; \mathrm{c}=P<0.001$. 
minus ENCAT 1992-93) and statistical significance are also presented.

Mean energy consumption changed very slightly $(-34 \mathrm{kcal})$, remaining at $1898 \mathrm{kcalday}^{-1}$ (2153 in males and 1678 in females), with positive or negative variations depending on age group and sex. This ranged from a maximum increase of $103 \mathrm{kcal}(P<0.001)$ in males aged 45-64 years and a maximum decrease of $-166 \mathrm{kcal}$ $(P<0.05)$ in females aged $10-17$ years. Protein consumption decreased by $-7 \mathrm{gday}^{-1}$ in both sexes $(P<0.001)$ at the expense of animal protein, decreasing the percentage of calories provided by protein from $20.2 \%$ to $19.2 \%(P<0.001)$.

Mean lipid consumption changed slightly, although it is worth highlighting the increase of more than $10 \mathrm{~g} \mathrm{day}^{-1}$ in males aged 45-64 years and the decrease of $10 \mathrm{~g} \mathrm{day}^{-1}$ in the youngest females. The percentage of calories provided by fats increased by $1.5 \%$, from $39.0 \%$ to $40.5 \%$, with a slight increase $(0.5 \%)$ in monounsaturated fatty acids (MUFA); in males aged 45-64 years fats increased by 3.8\%. Cholesterol decreased in all age groups and for both sexes $(P<0.001)$, with a mean decrease from 422 to $361 \mathrm{mg}$ day $^{-1}$ in males and from 331 to $280 \mathrm{mg} \mathrm{day}^{-1}$ in females.

Carbohydrate intake was maintained at $191 \mathrm{gday}^{-1}$ ( $216 \mathrm{~g} \mathrm{day}^{-1}$ in males and $170 \mathrm{~g} \mathrm{day}^{-1}$ in females) with a significant increase of about $10 \mathrm{~g} \mathrm{day}^{-1}$ in males aged 10-17 and 25-44 years, and in females aged 18-44 years. A decrease was observed in the other age groups. Males aged $25-44$ years showed a greater increase $\left(10 \mathrm{~g} \mathrm{day}^{-1}\right)$ in digestible sugars (mono and disaccharides), while females aged 18-44 years showed an increase in polysaccharides. The percentage of calories provided by carbohydrates increased $0.5 \%$ on average (from $40.6 \%$ to $41.1 \%$ ). Fibre intake decreased slightly in the entire sample by $-1.1 \mathrm{~g} \mathrm{day}^{-1}$ (from a mean of 19.1 to $18.0 \mathrm{~g} \mathrm{day}^{-1}$ ).

With respect to minerals, calcium intake increased $(P<0.001)$ in the whole sample $\left(+61.2 \mathrm{mgday}^{-1}\right.$ in males and +53.2 in females $)$, and a decrease $(P<0.001)$ was observed in the intake of potassium $\left(-256 \mathrm{mg} \mathrm{day}^{-1}\right.$ in males and -239 in females), iron $\left(-1.6 \mathrm{mg} \mathrm{day}^{-1}\right.$ in males and -1.4 in females $)$ and zinc $\left(-0.7 \mathrm{mg} \mathrm{day}^{-1}\right.$ in both sexes). Sodium intake increased in females aged 18-44 years and in adolescent males. Magnesium intake increased slightly only in the group aged 45-64 years $\left(+13.1 \mathrm{mg} \mathrm{day}^{-1}\right)$, while phosphorous intake increased only in males of this age group $\left(+61.2 \mathrm{mgday}^{-1}\right)$, decreasing in the other age groups and among females.

Regarding vitamins, the results from the whole sample showed a pronounced decrease in the intake of total

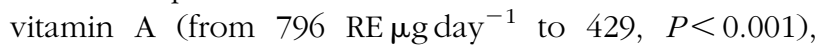
carotenoids (from 2869 to $1350 \mu \mathrm{g} \mathrm{day}^{-1}, P<0.001$ ) and retinoids (from 308 to $238 \mu \mathrm{g} \mathrm{day}^{-1}, P<0.01$ ). A lesspronounced decrease was observed in vitamin $D$ $\left(-0.2 \mu \mathrm{g} \mathrm{day}^{-1}\right.$ in males and $-0.9 \mu \mathrm{g} \mathrm{day}^{-1}$ in females), niacin $\left(-3.2 \mathrm{mg} \mathrm{day}^{-1}\right.$ in males and -2.7 in females) and vitamin $B_{12}\left(-1.6 \mu \mathrm{gday}^{-1}\right)$. Folate intake decreased $\left(-15 \mu \mathrm{g} \mathrm{day}^{-1}\right.$ on average) except for that of females aged 45-54 years. This age group also showed an increase in vitamin $C$ intake $\left(+17.6 \mathrm{mg} \mathrm{day}^{-1}\right)$, whereas the rest of the sample showed a decrease or no change at all (older males). Mean intake of the rest of the vitamins showed slight decreases with changes of positive and negative trends for the different age groups.

Tables 3 and 4 present the food group sources of energy and nutrients from the two surveys, in which small changes can be observed in the percentages. In ENCAT 2002-03, dairy products remain the main source of calcium (56\%), vitamin $\mathrm{B}_{2}(36 \%)$, saturated fatty acids (26\%), phosphorous (28\%) and magnesium (16\%). This was also true for retinoids (38\%) and potassium (16\%), since, contrary to what was observed in 1992-93, offal and fruits, respectively, were no longer their main source. Cereals remained the main contribution of vegetable protein (50\%), carbohydrates (38\%) and polysaccharides (65\%), fibre (28\%), sodium (24\%), energy (19\%) and iron (18\%). Fish remained the main source of vitamin $\mathrm{D}(65 \%)$ and vitamin $\mathrm{B}_{12}(35 \%)$. Meat was the main contributor of total protein (18\%), animal protein (24\%), zinc (23\%), niacin (19\%), thiamine (18\%) and vitamin $\mathrm{B}_{6}(13 \%)$. Edible fats were the main source of total fats (27\%), MUFA (40\%), polyunsaturated fatty acids (PUFA, $23 \%)$ and vitamin E (35\%). Eggs were the primary source of cholesterol (27\%). Fruits were the principal contributors of vitamin C (50\%) and of digestible sugars (28\%); vegetables were the main source of carotenoids (70\%), total vitamin A (38\%) and folates (25\%); non-alcoholic beverages were the primary source of water (49\%).

Tables 5-7 show the risk of inadequate energy and nutrient intakes by age group in ENCAT 1992-93 and ENCAT 2002-03 in males (Table 5) and females (Table 6) and in the total sample by gender together with the difference (ENCAT 2002-03 minus ENCAT 1992-93) of the percentages of inadequate intakes (Table 7). Nutritional adequacy is assessed in these tables through the use of five parameters: percentage population with intakes $<1 / 3$ of the RNI, $<1 / 2$ of the RNI, $<2 / 3$ of the RNI, or $<$ the RNI and the mean values for the percentages of the RNI. In general, a decrease in the percentage population with intakes $<1 / 3$ of the RNI of the studied nutrients was observed, and also the percentage with intakes $<1 / 2$ and $<2 / 3$ of the RNI except for vitamins A and D. Moreover, an increase in the percentage population with intakes under the RNI of zinc, magnesium, riboflavin, and vitamins D and $\mathrm{E}$ was observed. The mean values for the percentages of the RNI only increased for calcium, and the decrease in the percentages of the RNI for vitamin $\mathrm{B}_{12}$, vitamins $\mathrm{A}$ and $\mathrm{D}$, folates, niacin, iron and protein were noteworthy.

\section{Discussion}

This article presents data derived from the Catalan Nutrition Surveys conducted in 1992-93 (ENCAT 
Table 3 Food sources of energy and nutrients. Percent contribution of each food group. ENCAT 1992-93

\begin{tabular}{|c|c|c|c|c|c|c|c|c|c|c|c|c|c|c|c|c|c|c|c|c|}
\hline & $\begin{array}{l}\text { Dairy } \\
\text { products }\end{array}$ & Cereals & Pastry & Potatoes & Fish & Meats & Sausages & Offals & Poultry & $\begin{array}{l}\text { Edible } \\
\text { fats }\end{array}$ & Eggs & Pulses & Nuts & Fruits & Vegetables & $\begin{array}{l}\text { Sugar and } \\
\text { sweets }\end{array}$ & $\begin{array}{l}\text { Prepared } \\
\text { dishes }\end{array}$ & $\begin{array}{l}\text { Sauces and } \\
\text { condiments }\end{array}$ & $\begin{array}{l}\text { Non-alcoholic } \\
\text { beverages }\end{array}$ & $\begin{array}{c}\text { Alcoholic } \\
\text { beverages }\end{array}$ \\
\hline Energy & 10.8 & 18.0 & 7.1 & 5.0 & 4.4 & 7.6 & 5.0 & 0.1 & 4.2 & 9.3 & 1.9 & 1.8 & 0.6 & 7.1 & 2.1 & 3.1 & 4.7 & 2.1 & 2.6 & 2.5 \\
\hline Water & 11.7 & 4.6 & 0.3 & 2.6 & 2.8 & 2.8 & 1.0 & 0.1 & 1.8 & 0.0 & 0.8 & 0.8 & 0.0 & 14.7 & 9.2 & 0.1 & 2.0 & 0.7 & 39.5 & 4.5 \\
\hline Total proteins & 12.5 & 13.0 & 2.5 & 1.6 & 14.7 & 18.0 & 7.4 & 0.4 & 14.0 & 0.0 & 3.1 & 2.1 & 0.4 & 2.0 & 2.3 & 0.3 & 4.6 & 0.3 & 0.6 & 0.2 \\
\hline $\begin{array}{l}\text { Vegetable } \\
\text { proteins }\end{array}$ & 0.0 & 51.4 & 6.7 & 6.3 & 0.0 & 0.0 & 0.0 & 0.0 & 0.0 & 0.0 & 0.0 & 8.3 & 1.6 & 7.8 & 9.2 & 0.5 & 4.4 & 0.9 & 2.0 & 0.7 \\
\hline Animal proteins & 16.7 & 0.0 & 1.1 & 0.0 & 19.7 & 24.1 & 9.9 & 0.5 & 18.7 & 0.0 & 4.2 & 0.0 & 0.0 & 0.0 & 0.0 & 0.2 & 4.7 & 0.0 & 0.2 & 0.0 \\
\hline Total lipids & 13.8 & 3.0 & 7.7 & 4.2 & 3.8 & 10.6 & 8.9 & 0.1 & 3.9 & 23.8 & 3.2 & 1.4 & 1.3 & 1.3 & 0.7 & 0.7 & 6.3 & 4.8 & 0.5 & 0.0 \\
\hline SFA & 26.0 & 2.1 & 12.6 & 1.6 & 2.3 & 13.6 & 9.7 & 0.1 & 3.7 & 12.8 & 2.9 & 1.4 & 0.5 & 0.7 & 0.4 & 1.1 & 5.7 & 2.2 & 0.6 & 0.0 \\
\hline MUFA & 9.2 & 1.2 & 5.9 & 2.1 & 3.2 & 10.7 & 9.3 & 0.1 & 3.8 & 35.0 & 2.9 & 0.8 & 1.5 & 1.9 & 0.3 & 0.6 & 6.2 & 4.8 & 0.5 & 0.0 \\
\hline PUFA & 3.4 & 5.5 & 4.0 & 15.4 & 6.9 & 5.7 & 6.5 & 0.1 & 4.9 & 18.5 & 2.5 & 2.8 & 2.8 & 1.1 & 2.0 & 0.3 & 6.9 & 10.3 & 0.3 & 0.0 \\
\hline Cholesterol & 12.3 & 0.1 & 4.4 & 0.1 & 15.1 & 15.1 & 6.6 & 1.9 & 11.3 & 1.0 & 20.9 & 0.0 & 0.0 & 0.0 & 0.0 & 0.0 & 10.3 & 0.7 & 0.1 & 0.0 \\
\hline Carbohydrates & 7.5 & 35.5 & 8.8 & 7.5 & 0.1 & 0.0 & 0.2 & 0.0 & 0.0 & 0.0 & 0.0 & 2.1 & 0.1 & 15.3 & 3.3 & 6.8 & 6.0 & 0.6 & 5.7 & 0.4 \\
\hline $\begin{array}{l}\text { Digestible } \\
\text { sugars }\end{array}$ & 17.2 & 3.7 & 6.1 & 0.3 & 0.0 & 0.0 & 0.3 & 0.0 & 0.0 & 0.0 & 0.1 & 0.4 & 0.1 & 34.7 & 6.3 & 15.7 & 0.7 & 0.9 & 12.6 & 0.9 \\
\hline Polysaccharides & 0.1 & 62.8 & 11.5 & 13.7 & 0.2 & 0.0 & 0.1 & 0.0 & 0.0 & 0.0 & 0.0 & 3.5 & 0.1 & 0.5 & 1.0 & 0.1 & 5.5 & 0.3 & 0.5 & 0.0 \\
\hline Fibre & 0.2 & 27.1 & 4.4 & 6.6 & 0.1 & 0.0 & 0.0 & 0.0 & 0.0 & 0.0 & 0.0 & 10.8 & 0.9 & 24.2 & 19.4 & 0.4 & 3.1 & 1.1 & 1.6 & 0.0 \\
\hline Sodium & 8.5 & 27.7 & 4.1 & 0.3 & 5.1 & 3.7 & 19.0 & 0.1 & 1.4 & 0.0 & 1.9 & 0.7 & 0.1 & 7.1 & 2.3 & 0.1 & 6.1 & 3.8 & 7.7 & 0.5 \\
\hline Potassium & 12.8 & 5.4 & 1.6 & 9.8 & 6.6 & 7.6 & 2.7 & 0.2 & 4.6 & 0.0 & 1.0 & 3.1 & 0.4 & 19.4 & 13.9 & 0.3 & 4.2 & 1.5 & 2.9 & 1.9 \\
\hline Calcium & 53.7 & 8.4 & 2.8 & 0.9 & 4.2 & 1.1 & 0.6 & 0.0 & 0.8 & 0.0 & 1.7 & 1.4 & 0.4 & 6.1 & 6.8 & 0.4 & 4.0 & 0.5 & 5.7 & 0.7 \\
\hline Magnesium & 14.6 & 14.5 & 2.8 & 5.5 & 8.2 & 5.3 & 2.2 & 0.1 & 4.0 & 0.0 & 0.9 & 3.4 & 1.9 & 12.2 & 9.1 & 0.6 & 3.6 & 0.8 & 7.1 & 3.1 \\
\hline Phosphorus & 25.0 & 10.7 & 3.0 & 2.3 & 11.9 & 11.3 & 5.3 & 0.3 & 7.6 & 0.0 & 3.5 & 2.3 & 0.7 & 3.8 & 4.1 & 0.3 & 4.6 & 0.5 & 1.6 & 1.1 \\
\hline Iron & 3.5 & 17.2 & 3.9 & 2.5 & 9.6 & 11.1 & 5.6 & 0.8 & 5.5 & 0.0 & $\begin{array}{l}3.2 \\
3.2\end{array}$ & 5.0 & 0.6 & 9.9 & 11.7 & 0.6 & 5.0 & 0.8 & 2.1 & 1.3 \\
\hline Zinc & 18.5 & 13.1 & 2.0 & 1.7 & 6.0 & 23.3 & 5.5 & 0.6 & 4.9 & 0.0 & 3.1 & 3.7 & 0.8 & 5.8 & 4.1 & 0.4 & 4.8 & 0.4 & 1.0 & 0.3 \\
\hline Total vitamin A & 13.1 & 0.1 & 2.8 & 0.2 & 0.9 & 0.0 & 2.0 & 13.2 & 0.4 & 1.5 & 5.0 & 0.5 & 0.0 & 22.5 & 30.8 & 0.0 & 4.3 & 1.7 & 0.9 & 0.0 \\
\hline Retinoids & 30.3 & 0.1 & 5.9 & 0.2 & 2.0 & 0.0 & 4.5 & 33.4 & 1.1 & 3.4 & 12.3 & 0.0 & 0.0 & 0.0 & 0.0 & 0.0 & 5.7 & 0.8 & 0.3 & 0.0 \\
\hline Carotenoids & 1.9 & 0.1 & 0.8 & 0.2 & 0.0 & 0.0 & 0.4 & 0.1 & 0.0 & 0.3 & 0.2 & 0.9 & 0.0 & 37.2 & 50.9 & 0.0 & 3.4 & 2.2 & 1.3 & 0.0 \\
\hline Vitamin D & 5.9 & 2.4 & 3.6 & 0.0 & 61.9 & 0.0 & 3.0 & 0.3 & 3.1 & 0.7 & 12.3 & 0.0 & 0.0 & 0.0 & 0.0 & 0.0 & 6.3 & 0.2 & 0.1 & 0.0 \\
\hline Vitamin E & 2.9 & 1.6 & 3.2 & 2.1 & 8.9 & 0.9 & 0.6 & 0.1 & 0.8 & 29.4 & 2.5 & 1.8 & 5.4 & 12.7 & 10.0 & 1.0 & 8.3 & 7.5 & 0.4 & 0.0 \\
\hline Thiamine & 7.6 & 11.2 & 3.9 & 5.1 & 4.6 & 18.2 & 16.6 & 0.3 & 2.7 & 0.0 & 1.1 & 3.2 & 1.1 & 9.3 & 8.0 & 0.1 & 3.9 & 0.7 & 2.2 & 0.0 \\
\hline Riboflavin & 30.0 & 6.3 & 2.7 & 1.4 & 4.2 & 11.0 & 4.5 & 2.0 & 5.5 & 0.0 & 4.8 & 1.2 & 0.3 & 6.7 & 6.0 & 0.3 & 9.5 & 0.4 & 2.1 & 1.0 \\
\hline Niacin & 1.8 & 12.3 & 2.2 & 3.6 & 13.2 & 19.2 & 8.6 & 0.6 & 17.1 & 0.0 & 0.1 & 1.4 & 0.4 & 7.1 & 5.0 & 0.1 & 3.4 & 0.5 & 2.7 & 0.9 \\
\hline Vitamin $B_{6}$ & 7.3 & 7.7 & 2.6 & 7.1 & 12.0 & 13.1 & 6.4 & 0.4 & 11.6 & 0.0 & 1.3 & 2.5 & 0.4 & 10.5 & 9.7 & 0.2 & 4.5 & 0.8 & 0.8 & 1.1 \\
\hline Folates 6 & 7.0 & 14.9 & 2.6 & 6.0 & 3.0 & 1.8 & 1.8 & 1.1 & 1.5 & 0.0 & 3.6 & 7.2 & 1.0 & 17.4 & 24.6 & 0.1 & 3.9 & 0.7 & 1.1 & 0.7 \\
\hline Vitamin $B_{12}$ & 12.9 & 0.2 & 0.3 & 0.0 & 35.3 & 16.5 & 4.8 & 9.0 & 11.1 & 0.0 & 3.7 & 0.0 & 0.0 & 0.0 & 0.0 & 0.0 & 5.4 & 0.2 & 0.1 & 0.6 \\
\hline Vitamin C & 2.9 & 0.2 & 0.1 & 6.4 & 0.0 & 0.1 & 0.9 & 0.2 & 0.0 & 0.0 & 0.0 & 1.1 & 0.0 & 52.3 & 30.4 & 0.0 & 2.2 & 1.6 & 1.4 & 0.0 \\
\hline
\end{tabular}

SFA - saturated fatty acids; MUFA - monounsaturated fatty acids; PUFA - polyunsaturated fatty acids.

In bold the three main food sources of each nutrient. 
Table 4 Food sources of energy and nutrients. Percent contribution of each food group. ENCAT 2002-03

\begin{tabular}{|c|c|c|c|c|c|c|c|c|c|c|c|c|c|c|c|c|c|c|c|c|}
\hline & $\begin{array}{l}\text { Dairy } \\
\text { products }\end{array}$ & Cereals & Pastry & Potatoes & Fish & Meats & Sausages & Offals & Poultry & $\begin{array}{l}\text { Edible } \\
\text { fats }\end{array}$ & Eggs & Pulses & Nuts & Fruits & Vegetables & $\begin{array}{l}\text { Sugar and } \\
\text { sweets }\end{array}$ & $\begin{array}{l}\text { Prepared } \\
\text { dishes }\end{array}$ & $\begin{array}{l}\text { Sauces and } \\
\text { condiments }\end{array}$ & $\begin{array}{l}\text { Non alcoholic } \\
\text { beverages }\end{array}$ & $\begin{array}{c}\text { Alcoholic } \\
\text { beverages }\end{array}$ \\
\hline Energy & 11.8 & 18.8 & 7.8 & 4.4 & 4.1 & 7.4 & 4.7 & 0.1 & 3.5 & 10.8 & 2.2 & 2.1 & 1.2 & 5.8 & 2.1 & 3.2 & 2.7 & 1.5 & 3.4 & 2.4 \\
\hline Water & 12.4 & 4.6 & 0.4 & 2.1 & 2.2 & 2.2 & 0.9 & 0.0 & 1.4 & 0.0 & 0.9 & 1.0 & 0.0 & 9.5 & 8.0 & 0.1 & 1.2 & 0.4 & 48.8 & 4.0 \\
\hline Total proteins & 15.0 & 13.7 & 3.0 & 1.5 & 13.9 & 17.5 & 7.5 & 0.2 & 11.1 & 0.0 & 3.9 & 2.7 & 0.7 & 1.7 & 2.5 & 0.6 & 2.8 & 0.3 & 1.1 & 0.2 \\
\hline $\begin{array}{l}\text { Vegetable } \\
\text { proteins }\end{array}$ & 0.2 & 50.3 & 7.5 & 5.6 & 0.0 & 0.0 & 0.0 & 0.0 & 0.0 & 0.0 & 0.0 & 9.9 & 2.7 & 6.3 & 9.4 & 0.8 & 3.6 & 0.6 & 2.3 & 0.7 \\
\hline Animal proteins & 20.5 & 0.1 & 1.3 & 0.0 & 19.1 & 23.9 & 10.3 & 0.3 & 15.2 & 0.0 & 5.4 & 0.0 & 0.0 & 0.0 & 0.0 & 0.6 & 2.5 & 0.1 & 0.7 & 0.0 \\
\hline Total lipids & 13.6 & 3.2 & 8.3 & 3.5 & 3.8 & 10.6 & 8.2 & 0.1 & 3.6 & 27.1 & 3.7 & 1.6 & 2.4 & 1.1 & 0.9 & 1.2 & 3.0 & 3.3 & 0.9 & 0.0 \\
\hline SFA & 26.4 & 2.1 & 13.7 & 1.3 & 2.3 & 12.7 & 9.4 & 0.1 & 3.5 & 13.8 & 3.5 & 1.4 & 0.7 & 0.6 & 0.4 & 1.8 & 3.3 & 1.8 & 1.2 & 0.0 \\
\hline MUFA & 9.1 & 1.4 & 6.4 & 1.6 & 2.7 & 9.9 & 8.6 & 0.0 & 3.4 & 40.4 & 3.3 & 0.9 & 2.2 & 1.4 & 0.3 & 1.1 & 3.1 & 3.6 & 0.6 & 0.0 \\
\hline PUFA & 3.2 & 6.3 & 4.8 & 11.7 & 7.6 & 5.5 & 6.0 & 0.0 & 5.0 & 22.7 & 2.8 & 3.6 & 6.6 & 1.1 & 3.0 & 0.4 & 2.9 & 6.1 & 0.4 & 0.0 \\
\hline Cholesterol & 13.5 & 0.2 & 7.3 & 0.0 & 14.4 & 15.7 & 6.8 & 0.6 & 9.5 & 0.6 & 27.3 & 0.0 & 0.0 & 0.0 & 0.0 & 0.1 & 2.9 & 0.6 & 0.5 & 0.0 \\
\hline Carbohydrates & 9.1 & 37.5 & 9.9 & 6.8 & 0.2 & 0.0 & 0.2 & 0.0 & 0.0 & 0.0 & 0.0 & 2.4 & 0.2 & 12.8 & 3.2 & 6.6 & 3.1 & 0.4 & 7.0 & 0.5 \\
\hline $\begin{array}{l}\text { Digestible } \\
\text { sugars }\end{array}$ & 20.7 & 3.3 & 7.2 & 0.2 & 0.0 & 0.1 & 0.3 & 0.0 & 0.0 & 0.0 & 0.1 & 0.5 & 0.3 & 28.3 & 6.2 & 14.9 & 0.6 & 0.6 & 15.6 & 1.1 \\
\hline Polysaccharides & 0.3 & 64.5 & 12.0 & 12.0 & 0.4 & 0.0 & 0.1 & 0.0 & 0.0 & 0.0 & 0.0 & 4.0 & 0.2 & 0.9 & 0.9 & 0.1 & 4.1 & 0.2 & 0.5 & 0.0 \\
\hline Fibre & 0.6 & 28.4 & 5.1 & 6.0 & 0.1 & 0.0 & 0.0 & 0.0 & 0.0 & 0.0 & 0.0 & 12.1 & 1.7 & 21.5 & 19.9 & 0.7 & 2.0 & 0.8 & 1.1 & 0.0 \\
\hline Sodium & 9.6 & 24.3 & 4.3 & 0.2 & 5.3 & 4.0 & 17.6 & 0.0 & 1.3 & 0.0 & 2.1 & 0.8 & 0.1 & 4.0 & 2.2 & 0.1 & 5.3 & 10.3 & 8.0 & 0.4 \\
\hline Potassium & 16.2 & 6.0 & 2.0 & 9.6 & 6.3 & 7.6 & 2.7 & 0.1 & 4.0 & 0.0 & 1.2 & 3.9 & 0.8 & 14.8 & 14.4 & 0.5 & 2.2 & 1.1 & 4.4 & 2.3 \\
\hline Calcium & 56.3 & 6.1 & 3.0 & 0.7 & 3.5 & 0.9 & 0.6 & 0.0 & 0.6 & 0.0 & 1.8 & 1.6 & 0.6 & 5.3 & 6.2 & 0.7 & 2.6 & 0.5 & 8.2 & 0.7 \\
\hline Magnesium & 16.2 & 15.0 & 3.0 & 4.8 & 7.0 & 4.6 & 2.0 & 0.0 & 3.1 & 0.0 & 1.1 & 4.1 & 2.8 & 10.3 & 9.1 & 1.0 & 1.9 & 1.1 & 9.5 & 3.2 \\
\hline Phosphorus & 28.4 & 11.3 & 3.5 & 2.1 & 11.0 & 10.5 & 5.0 & 0.2 & 5.7 & 0.0 & 4.1 & 2.8 & 1.2 & 2.7 & 4.2 & 0.7 & 2.8 & 0.4 & 2.3 & 1.1 \\
\hline Iron & 4.3 & 18.1 & 4.6 & 2.5 & 8.6 & 10.3 & 6.6 & 0.4 & 4.6 & 0.0 & 4.1 & 6.3 & 1.1 & 7.5 & 12.5 & 0.8 & 3.0 & 0.8 & 2.2 & 1.4 \\
\hline Zinc & 20.1 & 14.6 & 2.3 & 1.6 & 5.5 & 22.7 & 5.1 & 0.4 & 4.9 & 0.0 & 3.7 & 4.6 & 1.3 & 3.5 & 4.4 & 0.6 & 2.6 & 0.4 & 1.2 & 0.4 \\
\hline Total vitamin A & 18.8 & 0.1 & 4.9 & 0.1 & 1.5 & 0.0 & 2.9 & 8.5 & 0.7 & 1.6 & 8.1 & 0.6 & 0.0 & 8.2 & 37.5 & 0.2 & 2.6 & 1.8 & 1.9 & 0.0 \\
\hline Retinoids & 37.5 & 0.0 & 8.9 & 0.1 & 2.9 & 0.0 & 5.4 & 18.3 & 1.6 & 3.1 & 17.1 & 0.1 & 0.0 & 0.0 & 0.0 & 0.3 & 2.8 & 0.8 & 1.0 & 0.0 \\
\hline Carotenoids & 3.0 & 0.1 & 1.5 & 0.2 & 0.0 & 0.0 & 0.8 & 0.1 & 0.0 & 0.4 & 0.4 & 1.0 & 0.0 & 15.1 & 69.5 & 0.1 & 2.5 & 2.6 & 2.7 & 0.0 \\
\hline Vitamin D & 8.1 & 1.9 & 4.0 & 0.0 & 65.0 & 0.3 & 2.3 & 0.1 & 1.8 & 0.8 & 12.7 & 0.0 & 0.0 & 0.0 & 0.8 & 0.1 & 1.9 & 0.2 & 0.1 & 0.0 \\
\hline Vitamin E & 3.4 & 2.9 & 3.9 & 1.9 & 9.2 & 0.9 & 0.6 & 0.0 & 0.9 & 35.2 & 2.8 & 2.2 & 6.4 & 9.2 & 10.8 & 1.2 & 3.1 & 4.6 & 0.8 & 0.0 \\
\hline Thiamine & 8.8 & 11.6 & 4.5 & 4.6 & 3.7 & 17.6 & 15.4 & 0.1 & 2.5 & 0.0 & 1.3 & 3.5 & 1.7 & 8.9 & 8.0 & 0.3 & 3.6 & 0.5 & 3.4 & 0.0 \\
\hline Riboflavin & 35.8 & 6.4 & 3.3 & 1.3 & 3.7 & 10.6 & 4.3 & 1.0 & 4.9 & 0.0 & 5.9 & 1.5 & 0.6 & 5.5 & 6.5 & 0.7 & 3.2 & 0.3 & 3.2 & 1.2 \\
\hline Niacin & 2.3 & 12.6 & 2.6 & 3.7 & 13.5 & 19.2 & 9.3 & 0.4 & 15.7 & 0.0 & 0.1 & 1.6 & 0.7 & 4.2 & 6.1 & 0.2 & 2.4 & 0.4 & 4.0 & 1.0 \\
\hline Vitamin $B_{6}$ & 11.3 & 8.6 & 2.9 & 6.4 & 11.0 & 12.7 & 5.9 & 0.2 & 8.8 & 0.0 & 1.5 & 2.8 & 0.9 & 11.2 & 10.3 & 0.3 & 2.2 & 0.5 & 1.3 & 1.1 \\
\hline Folates & 7.2 & 13.3 & 2.7 & 5.0 & 2.5 & 1.5 & 1.1 & 0.6 & 1.5 & 0.0 & 3.9 & 8.1 & 1.9 & 19.6 & 25.1 & 0.3 & 2.0 & 0.5 & 2.6 & 0.6 \\
\hline Vitamin $B_{12}$ & 18.3 & 0.1 & 0.6 & 0.0 & 34.6 & 17.4 & 5.2 & 6.1 & 8.4 & 0.0 & 5.5 & 0.0 & 0.0 & 0.0 & 0.0 & 0.1 & 2.4 & 0.2 & 0.5 & 0.7 \\
\hline Vitamin C & 2.6 & 0.5 & 0.4 & 5.2 & 0.0 & 0.1 & 0.8 & 0.2 & 0.7 & 0.0 & 0.0 & 0.8 & 0.0 & 49.6 & 30.3 & 0.2 & 0.7 & 1.1 & 7.0 & 0.0 \\
\hline
\end{tabular}

SFA - saturated fatty acids; MUFA - monounsaturated fatty acids; PUFA - polyunsaturated fatty acids.

In bold the three main food sources of each nutrient. 
Table 5 Risk of inadequate nutrient intake in Catalan men in ENCAT 1992-93 and ENCAT 2002-03 by age groups

\begin{tabular}{|c|c|c|c|c|c|c|c|c|c|c|c|c|c|c|c|c|c|c|c|c|c|c|c|c|c|}
\hline \multirow[t]{3}{*}{ Age group } & \multicolumn{5}{|c|}{$10-17$ years } & \multicolumn{5}{|c|}{$18-24$ years } & \multicolumn{5}{|c|}{$25-44$ years } & \multicolumn{5}{|c|}{$45-64$ years } & \multicolumn{5}{|c|}{$65-75$ years } \\
\hline & \multicolumn{4}{|c|}{$\begin{array}{l}\% \text { of the sample with } \\
\text { intakes }\end{array}$} & \multirow[b]{2}{*}{$\begin{array}{c}\text { Mean of \% } \\
\text { RNI }\end{array}$} & \multicolumn{4}{|c|}{$\begin{array}{c}\% \text { of the sample with } \\
\text { intakes }\end{array}$} & \multirow[b]{2}{*}{$\begin{array}{l}\text { Mean of \% } \\
\text { RNI }\end{array}$} & \multicolumn{4}{|c|}{$\begin{array}{l}\% \text { of the sample with } \\
\text { intakes }\end{array}$} & \multirow[b]{2}{*}{$\begin{array}{l}\text { Mean of \% } \\
\text { RNI }\end{array}$} & \multicolumn{4}{|c|}{$\begin{array}{c}\% \text { of the sample with } \\
\text { intakes }\end{array}$} & \multirow[b]{2}{*}{$\begin{array}{l}\text { Mean of \% } \\
\text { RNI }\end{array}$} & \multicolumn{4}{|c|}{$\begin{array}{c}\% \text { of the sample with } \\
\text { intakes }\end{array}$} & \multirow[b]{2}{*}{$\begin{array}{c}\text { Mean of \% } \\
\text { RNI }\end{array}$} \\
\hline & $\begin{array}{l}<1 / 3 \\
\mathrm{RNI}\end{array}$ & $\begin{array}{l}<1 / 2 \\
\text { RNI }\end{array}$ & $\begin{array}{l}<2 / 3 \\
\mathrm{RNI}\end{array}$ & $<\mathrm{RNI}^{-}$ & & $\begin{array}{l}<1 / 3 \\
\mathrm{RNI}\end{array}$ & $\begin{array}{l}<1 / 2 \\
\mathrm{RNI}\end{array}$ & $\begin{array}{l}<2 / 3 \\
\mathrm{RNI}\end{array}$ & $<<$ & & $\begin{array}{l}<1 / 3 \\
\mathrm{RNI}\end{array}$ & $\begin{array}{l}<1 / 2 \\
\mathrm{RNI}\end{array}$ & $\begin{array}{l}<2 / 3 \\
\mathrm{RNI}\end{array}$ & $\stackrel{<}{\mathrm{RNI}}$ & & $\begin{array}{l}<1 / 3 \\
\mathrm{RNI}\end{array}$ & $\begin{array}{l}<1 / 2 \\
\text { RNI }\end{array}$ & $\begin{array}{l}<2 / 3 \\
\mathrm{RNI}\end{array}$ & $\mathrm{RNI}^{<}$ & & $\begin{array}{l}<1 / 3 \\
\text { RNI }\end{array}$ & $\begin{array}{l}<1 / 2 \\
\mathrm{RNI}\end{array}$ & $\begin{array}{l}<2 / 3 \\
\mathrm{RNI}\end{array}$ & $\stackrel{<}{\mathrm{RNI}}$ & \\
\hline \multicolumn{26}{|c|}{ ENCAT 1992-93 } \\
\hline Energy & 0.0 & 1.2 & 7.8 & 79.6 & 86.8 & 0.0 & 1.7 & 16.9 & 82.6 & 84.2 & 0.0 & 2.2 & 25.1 & 91.1 & 77.7 & 0.0 & 2.8 & 34.1 & 95.3 & 74.1 & 0.0 & 1.8 & 18.2 & 88.2 & 82.7 \\
\hline Proteins & 0.0 & 0.0 & 0.0 & 0.6 & 203.5 & 0.0 & 0.4 & 0.8 & 1.2 & 208.4 & 0.0 & 0.0 & 0.0 & 0.8 & 204.6 & 0.0 & 0.3 & 0.3 & 1.9 & 178.4 & 0.0 & 0.0 & 0.0 & 1.8 & 167.1 \\
\hline Calcium & 0.6 & 6.0 & 26.3 & 70.1 & 88.0 & 0.0 & 3.7 & 9.9 & 52.5 & 102.2 & 0.0 & 1.1 & 12.9 & 60.4 & 97.5 & 0.0 & 6.6 & 27.8 & 75.6 & 86.0 & 0.0 & 4.5 & 25.5 & 78.2 & 84.7 \\
\hline Iron & 0.0 & 2.4 & 7.8 & 50.9 & 103.7 & 0.8 & 0.8 & 5.0 & 24.0 & 140.3 & 0.0 & 0.3 & 0.3 & 11.3 & 147.6 & 0.3 & 0.6 & 1.3 & 15.0 & 136.8 & 0.0 & 0.9 & 2.7 & 16.4 & 137.1 \\
\hline Zinc & 1.8 & 12.0 & 48.5 & 94.0 & 68.9 & 0.8 & 10.7 & 39.3 & 87.2 & 73.7 & 1.9 & 17.5 & 50.7 & 93.3 & 68.9 & 2.8 & 26.9 & 66.6 & 96.9 & 60.8 & 2.7 & 31.8 & 79.1 & 100.0 & 56.8 \\
\hline Magnesium & 1.2 & 6.6 & 26.9 & 83.8 & 79.2 & 0.4 & 5.8 & 22.3 & 71.1 & 88.3 & 0.0 & 1.3 & 8.9 & 73.9 & 89.1 & 0.3 & 1.3 & 14.1 & 85.3 & 83 & 0.0 & 1.8 & 16.4 & 78.2 & 84.3 \\
\hline Thiamine & 0.0 & 0.6 & 4.2 & 14.4 & 151.7 & 0.8 & 2.1 & 5.0 & 21.1 & 135.4 & 0.3 & 1.1 & 5.1 & 31.8 & 125.6 & 0.3 & 0.9 & 4.7 & 38.4 & 114.7 & 0.0 & 0.0 & 1.8 & 15.5 & 144.1 \\
\hline Riboflavin & 0.0 & 0.6 & 3.0 & 34.1 & 114.5 & 0.0 & 3.3 & 11.2 & 55.8 & 99.4 & 0.0 & 1.6 & 13.7 & 59.3 & 97.9 & 0.3 & 1.3 & 9.4 & 60.9 & 96.8 & 0.0 & 0.0 & 4.5 & 46.4 & 108.3 \\
\hline Niacin & 0.0 & 0.0 & 2.4 & 24.0 & 126.7 & 0.8 & 3.3 & 8.3 & 28.5 & 130.0 & 0.3 & 0.8 & 3.8 & 24.3 & 132.2 & 0.0 & 0.3 & 4.1 & 25.3 & 131 & 0.0 & 0.0 & 0.9 & 15.5 & 154.0 \\
\hline Vitamin $\mathrm{B}_{6}$ & 0.0 & 1.8 & 7.2 & 46.7 & 104.9 & 0.0 & 2.1 & 6.6 & 34.3 & 114.3 & 0.0 & 0.8 & 4.0 & 32.6 & 117.9 & 0.3 & 2.2 & 7.2 & 46.9 & 106.9 & 0.0 & 0.0 & 8.2 & 44.5 & 106.3 \\
\hline Folates & 0.0 & 1.8 & 6.6 & 25.7 & 161.9 & 0.0 & 2.5 & 8.7 & 33.9 & 131.7 & 0.0 & 0.5 & 4.0 & 27.2 & 125.2 & 0.0 & 0.9 & 4.7 & 30.6 & & 0.0 & 0.0 & 7.3 & 29.1 & 136.0 \\
\hline Vitamin $B_{12}$ & 0.0 & 0.0 & 3.0 & 6.0 & 304.3 & 0.4 & 0.8 & 2.9 & 5.8 & 327.9 & 0.0 & 0.3 & 1.1 & 5.4 & 402 & 0.3 & 1.6 & 2.8 & 9.4 & 335 & 0.0 & 0.0 & 4.5 & 9.1 & 370.3 \\
\hline Vitami & 4.8 & 13.2 & 28.1 & 54.5 & 128.2 & 8.3 & 16.9 & 21.5 & 37.2 & 156.1 & 3.0 & 8.6 & 15.1 & 29.9 & 157.7 & 1.6 & 4.1 & 8.8 & 24.7 & 182 & 0.0 & 0.0 & 0.9 & 8.2 & 200.2 \\
\hline Vitamin A & 10.8 & 33.5 & 58.1 & 100.0 & 73.6 & 14.5 & 31.8 & 49.6 & 100.0 & 75.4 & 13.5 & 28.6 & 44.2 & 100.0 & 89.3 & 18.1 & 32.8 & 51.3 & 100.0 & 85.6 & 14.5 & 32.7 & 48.2 & 100.0 & 90.2 \\
\hline Vitamin D & 82.0 & 99.4 & 100.0 & 100.0 & & 52.5 & 72.7 & 82.6 & 86.4 & & 52.8 & 67.9 & 74.4 & 78.7 & 68.7 & 92.2 & 100.0 & 100.0 & 100.0 & & 67.3 & 76.4 & 79.1 & 80.0 & 65.3 \\
\hline Vitamin E & 6.6 & 19.2 & 34.7 & 69.5 & 89.0 & 6.6 & 21.1 & 36.0 & 73.6 & 83. & 4.9 & 15.4 & 32.1 & 65.8 & 89.0 & 4.7 & 20.3 & 41.9 & 78.4 & 77. & 7.3 & 20.9 & 48.2 & 76.4 & 80.4 \\
\hline \multicolumn{26}{|c|}{ ENCAT 2002-03 } \\
\hline Energy & 0.0 & 0.6 & 6.0 & 74.0 & & 0.0 & 2.4 & 25.0 & 90.1 & & 0.0 & 1.9 & 28.2 & 95.6 & & 0.0 & 0.4 & 22.2 & 94.8 & & 0.0 & 2.1 & 30.6 & 96.7 & 75.0 \\
\hline & & 0.0 & 0.0 & 0.0 & 205 & 0.0 & 0.0 & 0.0 & & & & 0.0 & 0.0 & 0 & & 0.0 & 0.0 & 0.0 & 0.0 & & & 0.0 & 0.0 & 0.8 & 144.0 \\
\hline Calcium & 0.0 & 0.9 & 11.0 & 62.6 & 95.4 & 0.0 & 0.8 & 6.8 & 47.5 & 112. & 0.0 & 0.0 & 1.6 & 45.2 & 104 & 0.0 & 0.3 & 6.0 & 58.4 & 96 & 0.0 & 0.8 & 5.7 & 66.7 & 93.6 \\
\hline & & 0.0 & 3.0 & 68.0 & & 0.0 & 0.0 & 2.4 & 17 & & 0.0 & 0.0 & 0.0 & 5. & & 0.0 & 0.0 & 0.0 & 0 & 131. & 0.0 & 0.0 & 0.0 & 17.1 & 110.9 \\
\hline & 0.0 & 6.7 & 42.3 & 99.2 & 69.0 & 0.0 & 9.2 & 48.0 & 99.3 & & 0.0 & 8.8 & 64.4 & 99.7 & 63 & 0.0 & 0.7 & 94.9 & 100.0 & & 0.0 & 56.3 & 98.4 & 100.0 & 49.9 \\
\hline $\mathrm{Mc}$ & 0.0 & 0.0 & 16.4 & 98.9 & & 0.0 & 2.4 & 19.1 & 79.7 & & 0.0 & 0.0 & 6.2 & 81.4 & & 0.0 & 0.0 & 2.1 & & 89 & 0.0 & 0.8 & 16.9 & 92.2 & 80.5 \\
\hline & 0.0 & 0.0 & 0.0 & 0.8 & 151. & 0.0 & 0.0 & 0.0 & 6.5 & 129 & 0.0 & 0.0 & 0.7 & 17 & 115 & 0.0 & 0.0 & 0.0 & 17.0 & 112 & 0.0 & 0.0 & 2.4 & 27.1 & 113.4 \\
\hline & 0.0 & 0.0 & 2.2 & 25.1 & 114.6 & 0. & 0.0 & 6.1 & 59.1 & & 0 & 0.3 & 6.8 & 73.1 & 90 & 0.0 & 0.0 & 1.4 & 66.6 & 96 & 0.0 & 0.0 & 5.4 & 53.5 & 96.9 \\
\hline & 0.0 & 0.0 & 0.0 & 16.4 & & 0.0 & 0.0 & 1.9 & 25.9 & & 0.0 & 0.0 & 0.0 & 19 & & 0.0 & 0.0 & 0.0 & 5.5 & 11 & 0.0 & 0.0 & 0.8 & 37.0 & 106.9 \\
\hline Vitamin $B_{6}$ & 0.0 & 0.0 & 1.5 & 29.1 & 110.8 & 0.0 & 0.5 & 4.7 & 37.2 & 111.8 & 0.0 & 0.0 & 0.9 & 27.9 & 113.5 & 0.0 & 0.0 & 0.0 & 14.5 & 110.9 & 0.0 & 0.0 & 1.7 & 65.3 & 93.8 \\
\hline & 0.0 & 0.0 & 0.0 & 8.2 & 159.5 & 0.0 & 1.9 & 3.5 & 34.0 & 112.6 & 0.0 & 0.0 & 0.8 & 25.4 & 116.7 & 0.0 & 0.0 & 0.0 & 4.0 & 124.4 & 0.0 & 0.0 & 1.8 & 26.3 & 114.9 \\
\hline Vitam & 0.0 & 0.0 & 0.0 & 0.0 & 234.0 & 0.0 & 0.0 & 0.0 & 0.8 & 250.5 & 0.0 & 0.0 & 0.0 & 0.0 & 245.7 & 0.0 & 0.0 & 0.0 & 0.0 & 260.2 & 0.0 & 0.0 & 0.0 & 0.0 & 186.8 \\
\hline & 0.0 & 0.0 & 10.8 & 41.7 & 120.1 & 0.0 & 0.0 & 0.0 & 32.1 & 124.1 & 0.0 & 0.2 & 1.2 & 18.3 & 159.7 & 0.0 & 0.0 & 0.0 & 7.4 & 183.2 & 0.0 & 0.0 & 0.0 & 7.7 & 200.5 \\
\hline & 0.0 & 29.4 & 90.3 & 100.0 & 55 & 0.3 & 28.8 & 83.9 & 100.0 & & 1.0 & 38.8 & 89.4 & 99.4 & 53 & 1.1 & 33.6 & 81.9 & 98.9 & 55 & 11.9 & 74.9 & 96.4 & 99.7 & 44.7 \\
\hline & 49.8 & 91.8 & 100.0 & 100.0 & 34.3 & 34.9 & 81.0 & 95.3 & 100.0 & 38.9 & 55.9 & 84.1 & 93.0 & 100.0 & 34.8 & 73.1 & 96.4 & 100.0 & 100.0 & 27.1 & 100.0 & 100.0 & 100.0 & 100.0 & 14.3 \\
\hline Vitamin E & 0.0 & 0.9 & 24.1 & 89.5 & 79.8 & 1.0 & 8.7 & 34.6 & 83.9 & 79.0 & 0.0 & 1.3 & 20.7 & 96.6 & 78.1 & 0.4 & 0.7 & 10.5 & 89.8 & 82.3 & 2.0 & 14.2 & 45.3 & 93.1 & 70.0 \\
\hline
\end{tabular}

$\mathrm{RNI}$ - recommended nutrient intake. 
Table 6 Risk of inadequate nutrient intake in Catalan women in ENCAT 1992-93 and ENCAT 2002-03 by age groups

\begin{tabular}{|c|c|c|c|c|c|c|c|c|c|c|c|c|c|c|c|c|c|c|c|c|c|c|c|c|c|}
\hline \multirow[t]{3}{*}{ Age group } & \multicolumn{5}{|c|}{$10-17$ years } & \multicolumn{5}{|c|}{$18-24$ years } & \multicolumn{5}{|c|}{$25-44$ years } & \multicolumn{5}{|c|}{ 45-64 years } & \multicolumn{5}{|c|}{$65-75$ years } \\
\hline & \multicolumn{4}{|c|}{$\begin{array}{c}\% \text { of the sample with } \\
\text { intakes }\end{array}$} & \multirow[b]{2}{*}{$\begin{array}{l}\text { Mean of \% } \\
\text { RNI }\end{array}$} & \multicolumn{4}{|c|}{$\begin{array}{c}\% \text { of the sample with } \\
\text { intakes }\end{array}$} & \multirow[b]{2}{*}{$\begin{array}{l}\text { Mean of \% } \\
\text { RNI }\end{array}$} & \multicolumn{4}{|c|}{$\begin{array}{c}\% \text { of the sample with } \\
\text { intakes }\end{array}$} & \multirow[b]{2}{*}{$\begin{array}{c}\text { Mean of \% } \\
\text { RNI }\end{array}$} & \multicolumn{4}{|c|}{$\begin{array}{c}\% \text { of the sample with } \\
\text { intakes }\end{array}$} & \multirow[b]{2}{*}{$\begin{array}{c}\text { Mean of \% } \\
\text { RNI }\end{array}$} & \multicolumn{4}{|c|}{$\begin{array}{c}\% \text { of the sample with } \\
\text { intakes }\end{array}$} & \multirow[b]{2}{*}{$\begin{array}{l}\text { Mean of \% } \\
\text { RNI }\end{array}$} \\
\hline & $\begin{array}{l}<1 / 3 \\
\mathrm{RNI}\end{array}$ & $\begin{array}{l}<1 / 2 \\
\text { RNI }\end{array}$ & $\begin{array}{l}<2 / 3 \\
\text { RNI }\end{array}$ & $\underset{\mathrm{RNI}}{<}$ & & $\begin{array}{l}<1 / 3 \\
\mathrm{RNI}\end{array}$ & $\begin{array}{l}<1 / 2 \\
\mathrm{RNI}\end{array}$ & $\begin{array}{l}<2 / 3 \\
\mathrm{RNI}\end{array}$ & $\underset{\mathrm{RNI}}{<}$ & & $\begin{array}{l}<1 / 3 \\
\mathrm{RNI}\end{array}$ & $\begin{array}{l}<1 / 2 \\
\mathrm{RNI}\end{array}$ & $\begin{array}{l}<2 / 3 \\
\mathrm{RNI}\end{array}$ & $\underset{\mathrm{RNI}}{<}$ & & $\begin{array}{l}<1 / 3 \\
\mathrm{RNI}\end{array}$ & $\begin{array}{l}<1 / 2 \\
\mathrm{RNI}\end{array}$ & $\begin{array}{l}<2 / 3 \\
\mathrm{RNI}\end{array}$ & $\underset{\mathrm{RNI}}{<}$ & & $\begin{array}{l}<1 / 3 \\
\mathrm{RNI}\end{array}$ & $\begin{array}{l}<1 / 2 \\
\mathrm{RNI}\end{array}$ & $\begin{array}{l}<2 / 3 \\
\mathrm{RNI}\end{array}$ & $\underset{\mathrm{RNI}}{<}$ & \\
\hline \multicolumn{26}{|c|}{ ENCAT 1992-93 } \\
\hline Energy & 0.0 & 2.0 & 12.8 & 73.0 & 88.9 & 0.0 & 3.3 & 24.1 & 89.0 & 79.1 & 0.0 & 3.3 & 27.1 & 97.2 & 74.6 & 0.3 & 4.8 & 26.3 & 86.3 & 78.7 & 0.0 & 1.3 & 9.7 & 85.7 & 83.1 \\
\hline Proteins & 0.0 & 0.0 & 0.0 & 0.7 & 216.3 & 0.0 & 0.0 & 0.3 & 2.3 & 212.5 & 0.0 & 0.0 & 0.2 & 2.4 & 209.2 & 0.0 & 0.0 & 0.3 & 2.7 & 206.6 & 0.0 & 0.0 & 0.0 & 3.9 & 193.7 \\
\hline Calciu & 2.7 & 15.5 & 33.8 & 77.0 & 81.5 & 0.3 & 8.4 & 25.4 & 70.9 & 88.3 & 0.0 & 3.5 & 18.3 & 67.9 & 90.8 & 0.0 & 3.0 & 16.4 & 75.0 & 87.1 & 0.0 & 1.9 & 11.0 & 84.4 & 85.3 \\
\hline Iron & 2.7 & 10.8 & 43.9 & 91.9 & 71.2 & 6.4 & 23.7 & 57.2 & 94.6 & 64.6 & 2.4 & 19.7 & 56.8 & 95.4 & 66.0 & 0.5 & 3.2 & 14.2 & 46.0 & 107.7 & 0.0 & 1.3 & 2.6 & 36.4 & 110.6 \\
\hline Zinc & 5.4 & 29.7 & 58.8 & 94.6 & 63.4 & 9.0 & 37.5 & 70.6 & 98.0 & 57.6 & 7.9 & 35.2 & 75.1 & 97.8 & 56.6 & 9.9 & 42.2 & 80.9 & 98.1 & 54.5 & 12.3 & 59.1 & 87.7 & 99.4 & 48.7 \\
\hline Magnesium & 0.0 & 2.0 & 19.6 & 82.4 & 85.1 & 0.7 & 9.7 & 30.4 & 86.0 & 78.4 & 0.0 & 4.6 & 22.1 & 88.4 & 79.4 & 0.3 & 2.2 & 16.4 & 75.0 & 87.9 & 0.6 & 3.9 & 13.0 & 74.0 & 89.8 \\
\hline Thiamine & 0.0 & 0.7 & 2.7 & 12.2 & 161.9 & 0.0 & 0.7 & 5.4 & 19.7 & 140.2 & 0.0 & 1.5 & 4.1 & 26.4 & 130.1 & 0.5 & 1.1 & 4.3 & 21.0 & 133.5 & 0.6 & 1.3 & 1.9 & 17.5 & 145.4 \\
\hline Riboflavin & 0.0 & 1.4 & 6.1 & 33.1 & 121.0 & 0.0 & 1.0 & 7.4 & 42.5 & 109.7 & 0.4 & 1.5 & 6.6 & 41.5 & 112.9 & 0.3 & 0.5 & 5.1 & 24.7 & 124 & 0.0 & 0.6 & 1.9 & 11.0 & 134.6 \\
\hline Niacin & 0.0 & 0.7 & 1.4 & 17.6 & 132.6 & 0.0 & 2.0 & 6.7 & 26.4 & 136.2 & 0.2 & 0.9 & 2.6 & 13.1 & 133.3 & 0.0 & 1.1 & 2.7 & 13.7 & 157 & 0.0 & 0.0 & 0.0 & 0.0 & 155.7 \\
\hline Vitamin $\mathrm{B}_{6}$ & 0.7 & 3.4 & 14.2 & 52.0 & 100.9 & 0.7 & 4.0 & 9.7 & 46.2 & 106.1 & 0.4 & 1.7 & 7.0 & 40.4 & 108.9 & 0.5 & 1.9 & 9.4 & 41.1 & 108 & 0.0 & 2.6 & 9.1 & 50.0 & 103.2 \\
\hline Folate & 8.8 & $\begin{array}{r}3.4 \\
25.7\end{array}$ & $\begin{array}{l}51.4 \\
51.2\end{array}$ & 66.9 & 155.1 & 16.7 & 47.5 & $\begin{array}{r}7.1 \\
72.2\end{array}$ & 94.3 & 111.4 & $\begin{array}{l}0.4 \\
10.0\end{array}$ & 38.6 & 71.8 & 94.5 & 116.2 & 1.1 & 9.4 & $\begin{array}{r}5.4 \\
22.6\end{array}$ & 48.7 & 116 & 0.0 & $\begin{array}{l}2.0 \\
2.6\end{array}$ & 7.1 & 26.0 & 117.0 \\
\hline Vitamin $B_{12}$ & 2.7 & 2.7 & 2.7 & 12.8 & 322.6 & 0.3 & 1.3 & 6.0 & 15.1 & 328.8 & 0.2 & 0.4 & 1.3 & 3.7 & 242.1 & 0.0 & 0.0 & 0.0 & 0.0 & 217.0 & 0.0 & 1.9 & 1.9 & 1.9 & 174.7 \\
\hline Vitamin C & 4.1 & 12.8 & 20.9 & 47.3 & 124.9 & 4.3 & 10.7 & 18.7 & 39.8 & 142. & 1.5 & 5.0 & 8.1 & 21.8 & 185.1 & 0.5 & 1.9 & 5.1 & 13.2 & & 0.6 & 3.2 & 5.8 & 14.3 & 204.9 \\
\hline Vitami & 0.0 & 2.0 & 51.4 & 100.0 & & 0.0 & 1.3 & 27.8 & 100.0 & 71.9 & 7.4 & 16.8 & 26.4 & 100.0 & 122.3 & 9.1 & 18.3 & 29.3 & 100.0 & 107 & 0.0 & 3.2 & 87.0 & 100.0 & 60.6 \\
\hline Vitamin D & 89.9 & 100.0 & 100.0 & 100.0 & 22.9 & 80.9 & 99.3 & 100.0 & 100.0 & 25.6 & 87.8 & 92.6 & 94.3 & 95.9 & 30.1 & 84.1 & 89.2 & 90.6 & 91.9 & 37.4 & 100.0 & 100.0 & 100.0 & 100.0 & 14.0 \\
\hline \multirow{2}{*}{\multicolumn{26}{|c|}{$\begin{array}{l}\text { Vitamin E } \\
\text { ENCAT 2002-03 }\end{array}$}} \\
\hline & & & & & & & & & & & & & & & & & & & & & & & & & \\
\hline Energy & 0.0 & 0.0 & 5.2 & 100.0 & 82.5 & 0.2 & 1.6 & 18.4 & 85.6 & 82.1 & 0.8 & 3.4 & 21.1 & 94.9 & 75.4 & 0.3 & 1.4 & 28.6 & 93.9 & 76.5 & 0.0 & 0.0 & 13.4 & 97.9 & 77.2 \\
\hline & 0.0 & 0.0 & 0.0 & 0.0 & 203. & 0.0 & 0.0 & 0.0 & 0.9 & 203 & 0.0 & 0.0 & 0.0 & 0.0 & 196 & 0.0 & 0.0 & 0.0 & 0.3 & & & 0.0 & 0.0 & 0.0 & 165.9 \\
\hline alcium & 0.0 & 4.2 & 15.1 & 82.5 & 84.2 & 0.0 & 0.7 & 5.3 & 65.2 & 94. & 0.0 & 0.3 & 4.1 & 63.8 & 96 & 0.3 & 0.3 & 5.0 & 55.8 & 98 & 0.0 & 0.0 & 2.6 & 79.0 & 90.1 \\
\hline & 0.0 & 7.3 & 70.8 & 98.6 & & 0.2 & 10.6 & 84.6 & 100.0 & & 0.5 & 12.4 & 85.5 & 99.4 & & 0.0 & 2.5 & 25.7 & 56.6 & 91 & 0.0 & 0.0 & 0.0 & 70.0 & 95.9 \\
\hline & 0.0 & 7.4 & 88.9 & 100.0 & & 0.2 & 13.2 & 96.5 & 100.0 & & 1.0 & 43.0 & 93.8 & 100.0 & & 1.0 & 52.6 & 98.3 & 100.0 & 49 & 0.2 & 88.5 & 100.0 & 100 & 45 \\
\hline Mas & 0.0 & 0.4 & 3.0 & 90.6 & 83 & 0.2 & 0.9 & 15.3 & 95.2 & 78 & 0.0 & 1.3 & 14.2 & 91.1 & 80 & 0.0 & 0.3 & 4.6 & 73.1 & 91 & 0.0 & 0.0 & 10.7 & 84 & 87.1 \\
\hline This & 0.0 & 0.0 & 0 & 1.4 & 138.2 & 0.0 & 0.2 & 0.2 & 2.0 & 140. & 0.0 & 0.0 & 0.8 & 6.6 & 125.4 & 0.0 & 0.3 & 0.3 & 6.4 & 128 & 0.0 & 0.0 & 0.2 & 14.3 & 129.0 \\
\hline & 0.0 & 0.0 & 2.5 & $\begin{array}{r}1.44 \\
25.2\end{array}$ & 11 & 0.2 & 0.2 & 1.6 & 39.6 & 104. & 0.3 & 0.5 & 2.0 & 44.1 & 105.0 & 0.3 & 0.3 & 0.6 & $\begin{array}{r}0.4 \\
19.3\end{array}$ & & 0.0 & 0.0 & 0.0 & 9.1 & 122.2 \\
\hline & 0. & 0.0 & 0.0 & 21.4 & & 0.0 & 0.2 & 0.9 & 18.7 & & 0. & 0.0 & 0.0 & 9.0 & & 0.0 & 0.0 & 0.0 & 5.2 & 122 & 0.0 & 0.0 & 0.0 & 0.8 & 125.0 \\
\hline Vitamin $B_{6}$ & 0.0 & 0.0 & 3.1 & 51.9 & 101.8 & 0.0 & 0.2 & 0.9 & 45.5 & 103.1 & 0.0 & 0.3 & 0.5 & 43.2 & 105.4 & 0.0 & 0.0 & 0.0 & 30.4 & 107.6 & 0.0 & 0.0 & 0.0 & 66.4 & 96.1 \\
\hline & 0.0 & 34.9 & 59.7 & 64.3 & & 2.1 & 53.4 & 95.2 & 100.0 & & 2.6 & 39.0 & 85.7 & 99.5 & & 0.2 & 8.4 & 25.2 & 39.9 & & 0.0 & 0.0 & 0.0 & 28.5 & 109.1 \\
\hline & 0.0 & 0.0 & 0.0 & 0. & & 0.9 & 0.9 & 0.9 & 0.9 & 199 & 0.3 & 0.3 & 0.3 & 0.3 & 197 & 0.0 & 0.0 & 0.3 & 0.3 & & 0.0 & 1.2 & 1.2 & 1.2 & 172.1 \\
\hline Vitam & 0.0 & 0.0 & 14.1 & 38.7 & 125.6 & 0.0 & 0.2 & 1.7 & 23.3 & 130.0 & 0.0 & 0.0 & 0.0 & 4.7 & 162.3 & 0.0 & 0.0 & 0.0 & 2.3 & 225.0 & 0.0 & 0.0 & 0.0 & 1.9 & 195.8 \\
\hline & 0.0 & 1.8 & 74.4 & 100.0 & 63.5 & 0.0 & 6.3 & 79.9 & 99.6 & & 0.3 & 8.3 & 78.3 & 99.8 & 60.4 & 1.2 & 12.7 & 53.4 & 97.4 & 67.4 & 0.0 & 56.0 & 100.0 & 100.0 & 50.4 \\
\hline & 61.2 & 95.2 & 100.0 & 100.0 & & 71.6 & 96.8 & 100.0 & 100.0 & & 79.1 & 90.3 & 96.5 & 100.0 & 27.5 & 100.0 & 100.0 & 100.0 & 100.0 & 19.5 & 100.0 & 100.0 & 100.0 & 100.0 & 12.8 \\
\hline Vitamin $\mathrm{E}$ & 0.0 & 1.3 & 43.3 & 96.2 & 71.4 & 0.5 & 8.7 & 46.0 & 96.0 & 69.5 & 1.1 & 9.5 & 44.9 & 96.7 & 69.4 & 0.8 & 4.0 & 30.1 & 96.5 & 73.0 & 0.9 & 16.5 & 66.5 & 97.1 & 62.5 \\
\hline
\end{tabular}

$\mathrm{RNI}$ - recommended nutrient intake. 
Table 7 Differences (ENCAT 2002-03 minus ENCAT 1992-93) in risk of inadequate nutrient intake in the Catalan population aged 10-75 years

\begin{tabular}{|c|c|c|c|c|c|c|c|c|c|c|c|c|c|c|c|}
\hline & \multicolumn{5}{|c|}{ ENCAT 1992-93 } & \multicolumn{5}{|c|}{ ENCAT 2002-03 } & \multicolumn{5}{|c|}{ Differences (ENCAT 2002-03 minus ENCAT 1992-93) } \\
\hline & \multicolumn{4}{|c|}{$\%$ of the sample with intakes } & \multirow[b]{2}{*}{$\begin{array}{c}\text { Mean of \% } \\
\text { RNI }\end{array}$} & \multicolumn{4}{|c|}{$\%$ of the sample with intakes } & \multirow[b]{2}{*}{$\begin{array}{c}\text { Mean of \% } \\
\text { RNI }\end{array}$} & \multicolumn{4}{|c|}{$\%$ of the sample with intakes } & \multirow[b]{2}{*}{$\begin{array}{c}\text { Mean of \% } \\
\text { RNI }\end{array}$} \\
\hline & $\begin{array}{l}<1 / 3 \\
\mathrm{RNI}\end{array}$ & $\begin{array}{l}<1 / 2 \\
\mathrm{RNI}\end{array}$ & $\begin{array}{l}<2 / 3 \\
\mathrm{RNI}\end{array}$ & $\stackrel{<}{\mathrm{RNI}}$ & & $\begin{array}{l}<1 / 3 \\
\mathrm{RNI}\end{array}$ & $\begin{array}{l}<1 / 2 \\
\mathrm{RNI}\end{array}$ & $\begin{array}{l}<2 / 3 \\
\mathrm{RNI}\end{array}$ & $\stackrel{<}{\mathrm{RNI}}$ & & $\begin{array}{l}<1 / 3 \\
\mathrm{RNI}\end{array}$ & $\begin{array}{l}<1 / 2 \\
\mathrm{RNI}\end{array}$ & $\begin{array}{l}<2 / 3 \\
\mathrm{RNI}\end{array}$ & $\stackrel{<}{\mathrm{RNI}}$ & \\
\hline \multicolumn{16}{|l|}{ Men } \\
\hline Energy & 0.0 & 2.1 & 22.8 & 88.7 & 79.8 & 0.0 & 1.4 & 24.1 & 92.7 & 77.5 & 0.0 & -0.7 & 1.3 & 4.0 & -2.3 \\
\hline Proteins & 0.0 & 0.2 & 0.2 & 1.2 & 194.9 & 0.0 & 0.0 & 0.0 & 0.3 & 182.1 & 0.0 & -0.2 & -0.2 & -0.9 & -12.8 \\
\hline Calcium & 0.1 & 4.0 & 19.3 & 65.8 & 92.9 & 0.0 & 0.4 & 4.8 & 53.2 & 101.3 & -0.1 & -3.6 & -14.5 & -12.6 & 8.4 \\
\hline Iron & 0.2 & 0.8 & 2.7 & 20.7 & 136.2 & 0.0 & 0.0 & 0.6 & 13.0 & 123.3 & -0.2 & -0.8 & -2.1 & -7.7 & -12.9 \\
\hline Zinc & 2.0 & 19.2 & 54.9 & 93.7 & 66.6 & 0.0 & 11.5 & 72.3 & 99.7 & 62.1 & -2.0 & -7.7 & 17.4 & 6.0 & -4.5 \\
\hline Magnesium & 0.3 & 3.0 & 16.1 & 78.1 & 85.7 & 0.0 & 0.4 & 8.7 & 86.0 & 86.2 & -0.3 & -2.6 & -7.4 & 7.9 & 0.5 \\
\hline Thiamine & 0.3 & 1.1 & 4.5 & 27.5 & 130.0 & 0.0 & 0.0 & 0.5 & 15.3 & 119.6 & -0.3 & -1.1 & -4.0 & -12.2 & -10.4 \\
\hline Riboflavin & 0.1 & 1.6 & 9.8 & 54.4 & 101.2 & 0.0 & 0.1 & 4.6 & 62.7 & 95.9 & -0.1 & -1.5 & -5.2 & 8.3 & -5.2 \\
\hline Niacin & 0.2 & 1.0 & 4.3 & 24.5 & 132.8 & 0.0 & 0.0 & 0.3 & 17.8 & 114.9 & -0.2 & -1.0 & -4.0 & -6.7 & -17.9 \\
\hline Vitamin $B_{6}$ & 0.1 & 1.5 & 6.2 & 39.8 & 111.4 & 0.0 & 0.1 & 1.2 & 29.4 & 110.2 & -0.1 & -1.4 & -5.0 & -10.4 & -1.2 \\
\hline Folates & 0.0 & 1.2 & 5.8 & 29.4 & 132.4 & 0.0 & 0.2 & 0.9 & 18.8 & 122.5 & 0.0 & -1.0 & -4.9 & -10.6 & -9.9 \\
\hline Vitamin $B_{12}$ & 0.2 & 0.7 & 2.5 & 6.9 & 353.4 & 0.0 & 0.0 & 0.0 & 0.1 & 242.8 & -0.2 & -0.7 & -2.5 & -6.8 & -110.6 \\
\hline Vitamin C & 3.6 & 8.9 & 15.2 & 31.4 & 163.8 & 0.0 & 0.1 & 1.6 & 18.1 & 162.4 & -3.6 & -8.8 & -13.6 & -13.3 & -1.5 \\
\hline Vitamin A & $\begin{array}{r}14.6 \\
\text { (1) }\end{array}$ & 31.4 & 49.4 & 100.0 & 83.4 & 2.0 & 39.1 & 87.5 & 99.4 & 53.9 & -12.6 & 7.7 & 38.1 & -0.6 & -29.6 \\
\hline Vitamin D & 68.5 & 82.5 & 86.8 & 88.9 & 47.7 & 62.3 & 89.7 & 96.7 & 100.0 & 30.9 & -6.2 & 7.2 & 9.9 & 11.1 & -16.8 \\
\hline Vitamin E & 5.6 & 18.8 & 37.3 & 72.1 & 84.0 & 0.4 & 3.3 & 22.4 & 92.1 & 78.7 & -5.2 & -15.5 & -14.9 & 20.0 & -5.3 \\
\hline \multicolumn{16}{|l|}{ Women } \\
\hline Energy & 0.1 & 3.4 & 22.9 & 88.9 & 79.0 & 0.4 & 1.9 & 20.9 & 94.0 & 77.3 & 0.3 & -1.5 & -2.0 & 5.1 & -1.7 \\
\hline Proteins & 0.0 & 0.0 & 0.2 & 2.4 & 208.3 & 0.0 & 0.0 & 0.0 & 0.2 & 191.5 & 0.0 & 0.0 & -0.2 & -2.2 & -16.8 \\
\hline Calcium & 0.3 & 5.5 & 20.1 & 73.1 & 87.8 & 0.1 & 0.6 & 5.1 & 64.8 & 94.9 & -0.2 & -4.9 & -15.0 & -8.3 & 7.2 \\
\hline Iron & 2.5 & 13.3 & 38.6 & 75.7 & 81.9 & 0.2 & 7.5 & 57.0 & 83.6 & 72.7 & -2.3 & -5.8 & 18.4 & 7.9 & -9.2 \\
\hline Zinc & 8.9 & 39.5 & 75.3 & 97.8 & 56.1 & 0.7 & 44.6 & 95.8 & 100.0 & 51.4 & -8.2 & 5.1 & 20.5 & 2.2 & -4.7 \\
\hline Magnesium & 0.3 & 4.7 & 21.1 & 82.3 & 83.1 & 0.0 & 0.7 & 10.4 & 85.7 & 84.3 & -0.3 & -4.0 & -10.7 & 3.4 & 1.2 \\
\hline Thiamine & 0.2 & 1.1 & 4.1 & 21.2 & 138.0 & 0.0 & 0.1 & 0.4 & 6.5 & 129.6 & -0.2 & -1.0 & -3.7 & $\begin{array}{l}-14.7 \\
-14.7\end{array}$ & -8.4 \\
\hline Riboflavin & 0.2 & 1.0 & 5.8 & 33.2 & 118.3 & 0.2 & 0.3 & 1.6 & 30.8 & 110.0 & 0.0 & -0.7 & -4.2 & -2.4 & -8.3 \\
\hline Niacin & 0.1 & 1.0 & 3.1 & 15.1 & 142.4 & 0.0 & 0.0 & 0.1 & 9.1 & 121.3 & -0.1 & -1.0 & -3.0 & -6.0 & -21.2 \\
\hline Vitamin $B_{6}$ & 0.5 & 2.5 & 9.2 & 44.0 & 106.8 & 0.0 & 0.1 & 0.5 & 43.2 & 104.3 & -0.5 & -2.4 & -8.7 & -0.8 & -2.5 \\
\hline Folates & 7.9 & 27.7 & 50.0 & 72.3 & 119.5 & 1.3 & 27.3 & 57.6 & 71.5 & 77.0 & -6.6 & -0.4 & 7.6 & -0.8 & -42.5 \\
\hline Vitamin $B_{12}$ & 0.4 & 0.9 & 2.2 & 5.9 & 254.8 & 0.3 & 0.4 & 0.5 & 0.5 & 198.1 & -0.1 & -0.5 & -1.7 & -5.4 & -56.7 \\
\hline Vitamin $\mathrm{C}^{2}$ & 2.0 & 6.0 & 10.6 & 25.2 & 174.9 & 0.0 & 0.0 & 1.2 & 8.6 & 177.3 & -2.0 & -6.0 & -9.4 & -16.6 & 2.5 \\
\hline Vitamin A & 4.8 & 11.0 & 36.5 & 100.0 & 95.5 & 0.5 & 14.6 & 73.7 & 99.1 & 61.5 & -4.3 & 3.6 & 37.2 & -0.9 & -34.0 \\
\hline Vitamin D & 86.9 & 94.7 & 95.7 & 96.6 & 28.6 & 85.3 & 95.5 & 98.7 & 100.0 & 23.9 & -1.6 & 0.8 & 3.0 & 3.4 & -4.6 \\
\hline \multirow{2}{*}{\multicolumn{16}{|c|}{$\begin{array}{l}\text { Vitamin } \mathrm{E} \\
\text { Total }\end{array}$}} \\
\hline & & & & & & & & & & & & & & & \\
\hline Energy & 0.0 & 2.8 & 22.9 & 88.8 & 79.4 & 0.2 & 1.7 & 22.5 & 93.3 & 77.4 & 0.2 & -1.1 & -0.4 & 4.5 & -1.9 \\
\hline Proteins & 0.0 & 0.1 & 0.2 & 1.9 & 202.1 & 0.0 & 0.0 & 0.0 & 0.3 & 186.8 & 0.0 & -0.1 & -0.2 & -1.6 & -15.4 \\
\hline Calcium & 0.2 & 4.8 & 19.7 & 69.7 & 90.1 & 0.0 & 0.5 & 5.0 & 59.0 & 98.1 & -0.2 & -4.3 & -14.7 & -10.7 & 8.0 \\
\hline $\begin{array}{l}\text { Iron } \\
\text { Intul }\end{array}$ & 1.5 & $\begin{array}{l}4.0 \\
7.6\end{array}$ & $\begin{array}{l}22.1 \\
22.2\end{array}$ & 50.5 & $\begin{array}{l}50.1 \\
106.8\end{array}$ & 0.1 & 3.7 & 28.8 & 48.3 & 98.0 & -1.4 & $\begin{array}{l}-3.9 \\
-3.9\end{array}$ & 6.6 & -2.2 & $\begin{array}{r}0.0 \\
-8.8\end{array}$ \\
\hline Zinc & 5.7 & 30.2 & 66.0 & 95.9 & 60.9 & 0.4 & 28.0 & 84.1 & 99.9 & 56.8 & -5.3 & -2.2 & 18.1 & 4.0 & -4.2 \\
\hline Magnesium & 0.3 & 3.9 & 18.8 & 80.3 & 84.3 & 0.0 & 0.6 & 9.6 & 85.9 & 85.3 & -0.3 & -3.3 & -9.2 & 5.6 & 1.0 \\
\hline Thiamine & 0.3 & 1.1 & 4.3 & 24.1 & 134.3 & 0.0 & 0.1 & 0.5 & 10.9 & 124.6 & -0.3 & -1.0 & -3.8 & -13.2 & -9.7 \\
\hline Riboflavin & 0.2 & 1.3 & 7.6 & 42.9 & 110.4 & 0.1 & 0.2 & 3.1 & 46.8 & 103.0 & -0.1 & -1.1 & -4.5 & 3.9 & -7.5 \\
\hline Niacin & 0.2 & 1.0 & 3.6 & 19.4 & 138.0 & 0.0 & 0.0 & 0.2 & 13.5 & 118.1 & -0.2 & -1.0 & -3.4 & -5.9 & -20.0 \\
\hline Vitamin $B_{6}$ & 0.3 & 2.0 & 7.8 & 42.1 & 108.9 & 0.0 & 0.1 & 0.9 & 36.3 & 107.3 & -0.3 & -1.9 & -6.9 & -5.8 & -1.6 \\
\hline Folates & 4.3 & 15.5 & 29.8 & 52.7 & 125.4 & 0.7 & 13.7 & 29.3 & 45.2 & 99.8 & -3.6 & -1.8 & -0.5 & -7.5 & -25.6 \\
\hline Vitamin $B_{12}$ & 0.3 & 0.8 & 2.3 & 6.4 & 300.0 & 0.1 & 0.2 & 0.2 & 0.3 & 220.5 & -0.2 & -0.6 & -2.1 & -6.1 & -79.5 \\
\hline Vitamin $C^{12}$ & 2.8 & 7.3 & 12.7 & 28.0 & 169.8 & 0.0 & 0.1 & 1.4 & 13.4 & 169.8 & -2.8 & -7.2 & -11.3 & -14.6 & 0.0 \\
\hline Vitamin A & 9.3 & 20.3 & 42.4 & 100.0 & 90.0 & 1.2 & 26.8 & 80.6 & 99.3 & 57.7 & -8.1 & 6.5 & 38.2 & -0.7 & -32.3 \\
\hline Vitamin D & 78.5 & 89.1 & 91.6 & 93.1 & 37.3 & 73.8 & 92.6 & 97.7 & 100.0 & 27.4 & -4.7 & 3.5 & 6.1 & 6.9 & -9.9 \\
\hline Vitamin E & 6.5 & 21.9 & 44.0 & 78.7 & 77.8 & 0.6 & 5.7 & 32.8 & 94.3 & 74.2 & -5.9 & -16.2 & -11.2 & 15.6 & -3.6 \\
\hline
\end{tabular}


1992-93) and 2002-03 (ENCAT 2002-03) in representative population samples aged 10-75 years, and carried out under the auspices of the Health Department of the Catalan government. Both surveys follow very similar methodologies, having used the same food composition tables and the same nutritional assessment method consisting of two 24-hour recalls in part of or in the totality of the sample. This has allowed for the adjustment by intraindividual variability of energy and nutrients thus making them totally suitable for comparison ${ }^{20-23}$.

The analysis of intake trends requires the removal of the factors that can possibly mask the observed differences. This is why it is important to emphasise the fact that the data from ENCAT 1992-93 have been recoded and re-analysed according to the food composition tables used in ENCAT 2002-03. Food composition tables are one of the main causes of the differences found when comparing different studies, even if they have used identical methodology and only differ in the food composition tables $^{11}$. For example, the cholesterol content in a boiled egg according to the French table ${ }^{12}$ used in the first analysis of the surveys ENCAT 1992-93 was $500 \mathrm{mg}$ per $100 \mathrm{~g}$, while that of the Spanish tables used in ENCAT 2002-03 was $380 \mathrm{mg}$ per $100 \mathrm{~g}^{13}$. Therefore, the same data analysed with different tables would show a difference of $120 \mathrm{mg}$ per $100 \mathrm{~g}$ in a food habitually consumed $^{11}$.

Energy and nutrient intake trends reflect the variations observed in food intake: the increase in dairy products and their impact not only on calcium intake but also on other nutrients (being the main source of proteins, sugars, vitamins, etc.); the increase in nut consumption shown by the increase of the percentage of energy provided by total fats contained in this food group and especially of the percentage of PUFA (7\%); the decrease in the consumption of meat, offal and fish and its impact on the intake of proteins, retinoids, iron, vitamin $\mathrm{B}_{12}$; the decrease in the consumption of fruits and vegetables in a smaller proportion has had a considerable impact on the marked decrease of vitamin A and carotenoids, as well as on that of other nutrients such as fibre, potassium and folates; and the increase in the consumption of fruit juices, which contributed to the increase of vitamin $\mathrm{C}$ intake.

Changes caused not only by the quantitative variation but also by the qualitative variation are demonstrated as well. In other words, it is evident that global fruit consumption has decreased, but it is also evident that the most consumed fruits in the two surveys are not the same, and as such, their nutritional composition is not the same either. Thus, for example, in ENCAT 1992-93 melon was highly consumed, while in ENCAT 2002-03 citric fruits showed the highest consumption, with their consequent contribution to folate levels.

Another factor that could have influenced on the observed changes and could explain the decrease in fruit and vegetable consumption and, consequently, of carotenoids, etc., is seasonal variation ${ }^{24}$. In ENCAT 1992-93, the entire sample was firstly interviewed in a warm season, when a wide variety of fruit is available and bigger portions are consumed. When the consequences of the decrease of fruit consumption are analysed focussing on the main carotene sources, we observe that in ENCAT 1992-93 melon contributed to 24\%, raw carrot to $23 \%$ and boiled carrot to $10 \%$, peach to $9 \%$ and raw ripe tomato to $6 \%$; in total, these five foods contributed to $72 \%$ of the carotene intake $e^{11,25}$. Nevertheless, in ENCAT 2002-03, the five foods with the highest contribution to carotene intake were raw carrot (18\%) and boiled carrot (15\%), spinach (11\%), raw red tomato (9\%) and melon $(5 \%)$, with a total of $58 \%{ }^{11}$.

The increase in water consumption must be explained further, since in the ENCAT 1992-93 survey, data on consumption of drinking water were not adequately collected in all interviews. Moreover, the increase in sodium is also mainly caused by the fact that salt consumption was thoroughly collected in the second survey but not so in the first one.

Three points should be borne in mind when evaluating the results. First of all, the fact that the analysis includes the entire sample population without excluding underreporters, whose food under-reporting contributes to the under-estimation of mean energy and nutrient intakes and to the increase of inadequate intake percentages ${ }^{26,27}$. In ENCAT 1992-93, 32\% were under-reporters, while in 2002-03 it was $41 \%$, both determined according to the Goldberg method ${ }^{28}$. Therefore, the non-exclusion of underreporters could be slightly attenuating the trend ${ }^{26,27}$.

In addition, this analysis has not taken into account the intake of vitamin-mineral supplements, which, despite the fact that in Catalonia the percentage population consuming these products (8.3\%) is not as high as in other countries, it could also contribute to the increase of some nutrient values ${ }^{29}$. And finally, it should also be taken into account that fortified foods have not totally been considered. The consumption of this type of food is relatively 'modern' and the food composition tables used hardly include them. All this may contribute to results that over-estimate low intakes of certain nutrients and that the 'problem' really turns into a smaller one.

In summary, no relevant changes in energy intake trends were observed, although they were observed in some nutrients, with special mention of the daily decrease in the consumption of proteins $(-7 \mathrm{~g})$, cholesterol $(-56 \mathrm{mg})$, potassium $(-245 \mathrm{mg})$, vitamin A ( $-283 \mathrm{RE} \mu \mathrm{g})$, retinoids $(-71 \mu \mathrm{g})$, carotenoids $(-1520 \mu \mathrm{g})$, niacin $(-29 \mathrm{mg})$, folates $(-15 \mu \mathrm{g})$, vitamin $\mathrm{B}_{12}(-1.6 \mu \mathrm{g})$ vita$\min \mathrm{D}(-0.5 \mu \mathrm{g})$, fibre and iron, and of the increase in the consumption of calcium $(+57 \mathrm{mg})$ and the slight increase in lipids and fatty acids as percentage of energy. In general, the most outstanding trends were those of decreased vitamin A (as a result of the decreased consumption of offal), proteins, vitamin $\mathrm{D}$ and $\mathrm{B}_{12}$ (due to the decreased 
consumption of meat and fish) and increased calcium (as a consequence of the increased consumption of dairy products). No changes were observed in the energy intake of males or females. Therefore, the weight changes will have to be attributed to the changes in physical activity patterns. An increase in energy contributed by some foods with a poor nutritional profile has been identified, and these foods are especially consumed between meals as snacks. The risk of inadequate intakes increased for iron, and for vitamin $\mathrm{A}$ and $\mathrm{D}$, and decreased for calcium; the rest of nutrients did not show changes worth mentioning.

Data from the WHO-MONICA study in France describing nutritional trends from $1985-87$ to 1995-97 in individuals from 35 to 64 years, showed few changes in energy and macronutrient intakes. Protein consumption in French males remain stable whereas protein consumption in French females showed a slight increase (from 74.2 to $76.5 \mathrm{~g} \mathrm{day}^{-1}$ ), different from the tendency observed in the Catalan population where a decrease in the protein consumption was observed ${ }^{30}$. The most important variation was observed in the cholesterol intakes, which, as shown in our study, decreased (from 552 to $467 \mathrm{mg} \mathrm{day}^{-1}$ in male and from 447 to $385 \mathrm{mg}$ day $^{-1}$ in female). Referring to the fat intake data, it is noteworthy that in France and Catalonia, there was an improvement in the fat intake quality, with an increase in the ratio PUFA/SFA (saturated fatty acids) for both males and females, although the percentage of the SFA intake was superior in France (15.7\% energy in males and 16.1\% energy in females) than the values registered in Catalonia $(12.6 \% \text { and } 12.5 \% \text {, respectively })^{30}$. Compared with data from other countries, the total fat intake in Catalonia may be considered high. In Austria ${ }^{31}$ (individuals from 25 to 64 years), and the United Kingdom ${ }^{32}$ (individuals from 19 to 64 years) $35 \%$ of energy intake came from fat intake; in Finland ${ }^{33} 34 \%$ and in the Netherlands ${ }^{34} 37 \%$. Countries with available data on fat intake trends showed a decrease in the total fat intake of the population, although the proportions were still high: in the USA ${ }^{35,36}$ fat intake fell from 39\% to 33\% between 1965 and 1996; in Finland $(1972-2002)^{33,37}$ it fell from $37 \%$ to $34 \%$. In Spain, as in other Mediterranean countries, the general WHO recommendations for fat are not easy to implement due to the high consumption of olive oil, which makes it difficult to reduce the contribution of energy from fat to 30\%. The Spanish Society of Community Nutrition (SENC) recommends a total fat consumption of $35 \%$ of energy when olive oil is the edible fat used ${ }^{38,39}$. In Catalonia, although up to $41 \%$ of the energy intake comes from fat, the saturated fat intake consumption is lower (12.6\%) than in other countries such as Austria ${ }^{31}$ (15.2\%), United Kingdom $^{32}(13.3 \%)$ or the Netherlands ${ }^{34}$ (14.7\%). Olive oil is responsible for $24 \%$ of the total fat intake in Catalonia.

The increased calcium intake in the whole population stands out unlike other countries such as the USA ${ }^{36}$ where the tendencies (1971-2000) showed a decrease in mean calcium intake for the population aged 3-15 years; however, average intakes in the USA were superior to the Catalan ones. The decrease in the consumption of vitamin A has also been observed in other countries such as the Netherlands (1987-98) ${ }^{34}$ as a consequence of the decrease in fruit and vegetable consumption. In the United Kingdom, trends (1986-2001) showed an increase in the mean intakes of certain vitamins and minerals, including thiamine, niacin, vitamin $\mathrm{B}_{6}$, folate, vitamin $\mathrm{C}$, vitamin $\mathrm{E}$, calcium, potassium and phosphorus.

When comparing data from the dietary sources of nutrients from Catalonia and Germany (data from results of the MONICA Projects Ausburg, 1984-85/1994-95 $5^{40}$ ), the different dietary pattern across Europe is seen. In Germany, although the 10-year trend on nutritional data (individuals from 45 to 64 years) showed a decrease in the importance of meat and meat products and eggs as contributors to the intake of energy and several nutrients, when compared to Catalonia, the percentages were still high. If we look at nutritional data from Germany 1994-95 and ENCAT 2002-03, the main sources of SFA were meat/ products (32\%), edible fats (31\%) and milk products (19.4\%) in Germany and 25\%, 25\% and 17\% in Catalonia, respectively. In Germany, the main source of MUFA was meat/products (41\%) and in Catalonia edible fats (46\%); of vitamin A meat/products (34\%) in Germany and vegetables (41\%) in Catalonia; of vitamin C vegetable products (61\%) in Germany and fruits (fruits 55\%) in Catalonia.

The results obtained with the evaluation of the risk for inadequate nutrient intakes must be used as a warning sign and must be corroborated with other more objective methods. The previously commented limitations in relation to the method (not excluding under-reporters, not incorporating of the contributions of supplements, etc.) and the limitations inherent to the proper value of the RNI require us to be cautious with the interpretation of the results ${ }^{26}$.

The results indicate a stabilisation of energy and nutrient intake in Catalonia from 1992 to 2003, as well as some deterioration in the quality of the diet expressed as a lower coverage of RNI for certain nutrients.

\section{Acknowledgements}

Sources of funding: This work was made possible by financing from the General Division of Public Health of the Generalitat of Catalonia's Department of Health, through a research agreement with the Fundación para la Investigación Nutricional (Nutrition Research Foundation).

Conflict of interest declaration: None of the authors had any conflicts of interest in connection with this study.

Authorship responsibilities: LSM was director of the study, was responsible for the interpretation of dietary 
data and the writing of the paper, LRB was responsible of the statistical analysis and the interpretation of dietary data, and also helped in writing and editing the article, GS participated in the study concept and design and provided expert advice on data interpretation, LJ was responsible for the statistical analysis (adjustments for intraindividual variability), BR and JN participated in the study concept and design, AP revised the paper providing expert advice on data interpretation.

\section{Guarantor: Lluís Serra-Majem.}

Special acknowledgement is made to all those persons who were interviewed, and whose collaboration made the realisation of these surveys possible.

Research Group on the Evaluation and Monitoring of the Nutritional Status in the Catalan Population: Lluís Serra-Majem, Director (University of Las Palmas de Gran Canaria); Lourdes Ribas-Barba, Coordinator (FIN Nutrition Research Foundation, Barcelona Science Park); Gemma Salvador (Generalitat of Catalonia); Conxa Castell (Generalitat of Catalonia); Blanca Román- Viñas (FIN, Barcelona Science Park); Jaume Serra (Generalitat of Catalonia); Lluís Jover (University of Barcelona); Ricard Tresserras (Generalitat of Catalonia); Blanca Raidó (FIN, Barcelona Science Park); Andreu Farran (CESNID, University of Barcelona); Joy Ngo (FIN, Barcelona Science Park); Mari Cruz Pastor (Hospital Germans Trias i Pujol, Badalona); Lluís Salleras (University of Barcelona); and Carmen Cabezas, Josep Lluís Taberner, Salvi Juncà, Josep Maria Aragay, Eulàlia Roure, Gonçal Lloveras Vallès $(†$ 2003), Antoni Plasencia (Generalitat of Catalonia).

\section{References}

1 World Health Organization. The World Health Report 2002Reducing Risks, Promoting Healthy Life. Geneva: World Health Organization, 2002.

2 World Health Organization. Diet, Nutrition and the Prevention of Chronic Diseases. Report of a Joint Food and Agriculture Organization of the United Nations/World Health Organization Expert consultation. World Health Organization Technical Report Series 916. Geneva: World Health Organization, 2003.

3 Jerome NW, Ricci JA. Food and nutrition surveillance: an international overview. American Journal of Clinical Nutrition 1997; 65(Suppl. 4): 1198S-202S.

4 Jelliffe DB, Jeliffe EFP. Community Nutritional Assessment. New York: Oxford University Press, 1989.

5 Serra Majem L, Ortiz Moncada MR. Planificación y programación en nutrición Comunitaria. In: Serra Majem L, Aranceta Bartrina J, eds. Nutrición y Salud Pública. Métodos, Bases Científicas y Aplicaciones, second edition. Barcelona: Masson, 2006; 676-83.

6 Generalitat de Catalunya. Framework document for the formulation of the Health Plan for Catalonia. Barcelona: Departament de Sanitat i Seguretat Social, 1991.

7 Generalitat de Catalunya. Estratègies de salud per a l'any 2010. Pla de salud de Catalunya. Barcelona: Departament de Sanitat i Seguretat Social, 2003.

8 Jiménez A, Cervera P, Sentis J, Canela J, Martínez JM, Lloveras $\mathrm{G}$, et al. Hàbits alimentaris $i$ consum d'aliments a Catalunya. Llibre Blanc. Barcelona: Servei de Promoció de la SalutDirecció General d'Ordenació i Planificació Sanitària; Generalitat de Catalunya, Departament de Sanitat i Seguretat Social, 1988.

9 Serra Majem L, Ribas Barba L, García Closas R, Ramon JM, Salvador G, Farran A, et al. Llibre Blanc: Avaluació de l'estat nutricional de la població catalana (1992-93). Barcelona: Departament de Sanitat i Seguretat Social, Generalitat de Catalunya, 1996; 1-252.

10 Serra Majem L, Ribas Barba L, Salvador Castell G, Castell Abat C, Román Viñas B, Serra Farró J, et al. Avaluació de l'estat nutricional de la població catalana 2002-2003. Evolució dels hàbits alimentaris $i$ dels consum d'aliments $i$ nutrients a Catalunya (1992-2003). Barcelona: Departament de Salut, Generalitat de Catalunya, 2006.

11 Ribas-Barba L, Serra-Majem L, Salvador G, Castell C, Cabezas C, Salleras L, Plasencia A. Trends in dietary habits and food consumption in Catalonia, Spain (1992-2003). Public Health Nutrition 2007; 10(11A): 1340-53.

12 Favier JC, Ireland-Ripert J, Toque C, Feinberg M. Répertoire général des aliments, second edition. Paris: Tec \& Doc Lavoisier, 1995.

13 CESNID. Tablas de Composición de Alimentos. Barcelona: Edicions Universitat de Barcelona-Centre d'Ensenyament Superior de Nutrició i Dietètica, 2002.

14 Beaton GH, Milner J, Corey P, McGuire V, Cousins M, Stewart $\mathrm{E}$, et al. Sources of variance in 24 hour dietary recall data; implications for nutrition study design and interpretation. American Journal of Clinical Nutrition 1979; 32: 2546-59.

15 Beaton GH, Milner J, McGuire V, Feather T, Little JA. Sources of variance in 24 hour dietary recall data: implications for nutrition study design and interpretation. Carbohydrate sources, vitamins and minerals. American Journal of Clinical Nutrition 1983; 37: 986-95.

16 Liu K, Stamler J, Dyer A, McKeever J, McKeever P. Statistical methods to assess and minimize the role of intraindividual variability in obscuring the relationship between dietary lipids and serum cholesterol. Journal of Chronic Diseases 1978; 31: 399-18.

17 Sempos CT, Johnson NE, Smith EL, Gilligan C. Effects of intraindividual and interindividual variation in repeated dietary recalls. American Journal of Epidemiology 1985; 121: $120-30$.

18 Centro Superior de Investigaciones Científicas (CSIC). Tablas de Ingestas Recomendadas en Energía y Nutrientes para la Población Española. Madrid: Instituto de Nutrición, Universidad Complutense de Madrid, 1994.

19 Gibson RS. Nutritional Assessment. A Laboratory Manual. New York: Oxford University Press, 1993.

20 Willett W, ed. Nutritional Epidemiology, second edition. New York: Oxford University Press, 1998.

21 World Health Organization. Methodology of Nutritional Surveillance. Report of a Joint FAO/UNICEF/WHO Expert Committee. World Health Organization Technical Report Series 1976(593): 1-66.

22 Serra Majem L, Sánchez Villegas A. Epidemiología nutricional. In: Serra Majem L, Aranceta Bartrina J, eds. Nutrición y Salud Pública. Métodos, Bases científicas y Aplicaciones, 2nd edn. Barcelona: Masson, 2006; 65-71.

23 Dubuisson C, Lioret S, Gautier A, Delamaire C, PerrinEscalon $\mathrm{H}$, Guilbert $\mathrm{P}$, et al. Comparaison de deux enquêtes nationales de consommations alimentaires (INCA 1 1998/99 et Baromètre santé nutrition 2002) au regard de cinq objectifs alimentaires du Programme national nutrition santé. Revue Epidemiologie et Sante Publique 2006; 54(1): 5.

24 Capita R, Alonso-Calleja C. Differences in reported winter and summer dietary intakes in young adults in Spain. International Journal of Food Sciences and Nutrition 2005; 56(6): 431-43. 
25 Gascón Vila P, Ribas L, García-Closas R, Farran Codina A. Serra-Majem L y Grupo de Investigación sobre el Estado Nutricional de la Población Catalana. Fuentes alimentarias de las vitaminas A, C, E y beta-caroteno en una población adulta mediterránea. Gaceta Sanitaria 1999; 13: 22-9.

26 Mackerras D, Rutishauser I. 24-Hour national dietary survey data: how do we interpret them most effectively? Public Health Nutrition 2005; 8(6): 657-65.

27 Murphy SP, Vorster HH. Methods for using nutrient intake values (NIVs) to assess or plan nutrient intakes. Food and Nutrition Bulletin 2007; 28(Suppl. 1): S51-60.

28 Goldberg GR, Black AE, Jebb SA, Cole TJ, Murgatroyd PR, Coward WA, et al. Critical evaluation of energy intake data using fundamental principles of energy physiology. 1. Derivation of cut-off limits to identify under-recording. European Journal of Clinical Nutrition 1991; 45: 569-81.

29 Serra-Majem L, Román-Viñas B, Salvador G, Ribas-Barba L, Ngo J, Castell C, Cabezas C. Knowledge, opinions and behaviours related to food and nutrition in Catalonia, Spain (1992-2003). Public Health Nutrition 2007; 10(11A): $1396-405$.

30 Perrin AE, Simon C, Hedelin G, Arveiler D, Schaffer P, Schlienger JL. Ten-year trends of dietary intake in a middleaged French population: relationship with educational level. European Journal of Clinical Nutrition 2002; 56(5): 393-401.

31 Elmadfa I, Freisling H. Austrian Nutrition Report 2003. English Summary. Vienna: Institute of Nutritional Sciences, University of Vienna - Federal Ministry of Health and Women, 2003.

32 Swan G. Findings from the latest National Diet and Nutrition Survey. Proceedings of the Nutrition Society 2004; 63(4): 505-12.
33 Finnish National Public Health Institute (KTL). The National Findiet 2002 Study. http://www.ktl.fi/portal/english/research_ people_programs/health_promotion_and_chronic_disease_ prevention/units/nutrition_unit/findiet_2002_study/. Accessed 5 July 2007.

34 Hulshof KF, Brussaard JH, Kruizinga AG, Telman J, Lowik MR. Socio-economic status, dietary intake and $10 \mathrm{y}$ trends: the Dutch National Food Consumption Survey. European Journal of Clinical Nutrition 2003; 57(1): 128-37.

35 Popkin BM, Siega-Riz AM, Haines PS, Jahns L. Where's the fat? Trends in US diets 1965-1996. Preventive Medicine 2001; 32(3): 245-54.

36 Briefel RR, Johnson CL. Secular trends in dietary intake in the United States. Annual Reviews of Nutrition 2004; 24 : 401-31.

37 Pietinen P, Vartiainen E, Seppanen R, Aro A, Puska P. Changes in diet in Finland from 1972 to 1992: impact on coronary heart disease risk. Preventive Medicine 1996; 25(3): 243-50.

38 Serra-Majem LL, Ribas L, Ramon JM. Compliance with dietary guidelines in the Spanish population. Results from the Catalan Nutrition Survey. British Journal of Nutrition 1999; 81(Suppl. 2): s105-12.

39 Serra-Majem L, Aranceta J, On behalf of the SENC Working Group on Nutritional Objectives for the Spanish Population. Nutritional objectives for the Spanish population. Consensus from the Spanish Society of Community Nutrition. Public Health Nutrition 2001; 4(6A): 1409-13.

40 Winkler G, Doring A, Keil U. Trends in dietary sources of nutrients among middle-aged men in southern Germany. Results of the MONICA Project Augsburg: Dietary Surveys 1984/1985 and 1994/1995. MONItoring trends and determinants in CArdiovascular disease. Appetite 2000; 34(1): $37-45$. 